\title{
Regulatory T Cells in the Tumor Microenvironment and Cancer Progression: Role and Therapeutic Targeting
}

\author{
Belal Chaudhary ${ }^{1}$ and Eyad Elkord ${ }^{2,3,4,5, *}$ \\ 1 Cancer Research UK Cambridge Institute, University of Cambridge, Cambridge CB2 ORE, UK; \\ belal.chaudhary@cantab.net \\ 2 Cancer Center, Qatar Biomedical Research Institute and College of Science and Engineering, \\ Hamad Bin Khalifa University, Qatar Foundation, Doha 5825, Qatar \\ 3 College of Medicine and Health Sciences, United Arab Emirates University, Al Ain 17666, UAE \\ 4 Institute of Cancer Sciences, University of Manchester, Manchester M20 4BX, UK \\ 5 Biomedical Research Centre, School of Environment and Life Sciences, University of Salford, \\ Salford M5 4WT, UK \\ * Correspondence: eelkord@qf.org.qa or e.elkord@salford.ac.uk or eelkord@uaeu.ac.ae; Tel.: +971-3-7137-527
}

Academic Editor: Theresa L. Whiteside Received: 14 June 2016; Accepted: 1 August 2016; Published: 6 August 2016

\begin{abstract}
Recent years have seen significant efforts in understanding and modulating the immune response in cancer. In this context, immunosuppressive cells, including regulatory $\mathrm{T}$ cells (Tregs) and myeloid-derived suppressor cells (MDSCs), have come under intense investigation for their proposed roles in suppressing tumor-specific immune responses and establishing an immunosuppressive tumor microenvironment, thus enabling tumor immune evasion. Additionally, recent evidence indicates that Tregs comprise diverse and heterogeneous subsets; phenotypically and functionally distinct subsets of tumor-infiltrating Tregs could contribute differently to cancer prognosis and clinical outcomes. Understanding Treg biology in the setting of cancer, and specifically the tumor microenvironment, is important for designing effective cancer therapies. In this review, we critically examine the role of Tregs in the tumor microenvironment and in cancer progression focusing on human studies. We also discuss the impact of current therapeutic modalities on Treg biology and the therapeutic opportunities for targeting Tregs to enhance anti-tumor immune responses and clinical benefits.
\end{abstract}

Keywords: regulatory $\mathrm{T}$ cells; tumor microenvironment; cancer progression; therapeutic targeting; tumor-infiltrating lymphocytes

\section{Introduction}

Regulatory T cells (Tregs) comprise diverse subsets of immunosuppressive cells that play critical roles in maintaining immune homeostasis and self-tolerance. They are also involved in controlling autoimmunity, infection, graft-versus-host disease, inflammation, fetal-maternal tolerance, and tumor immunity [1].

Tregs are broadly divided by lineage into thymic-derived tTregs, autoreactive $\mathrm{T}$ cells selected by high avidity interaction with self-antigens in the thymus, and peripheral pTregs, induced from naïve $\mathrm{CD}^{+} \mathrm{T}$ cells by sub-optimal antigen presentation in the periphery [2]. tTregs are crucial for preserving self-tolerance and preventing autoimmunity, while $p$ Tregs maintain peripheral tolerance at mucosal interfaces and in response to external antigens [1,3]. Both subsets of Tregs have traditionally been defined by expression of the Forkhead Box P3 (FoxP3) transcription factor-a "master regulator" of the suppressive lineage-and the IL-2 receptor $\alpha$ chain (CD25) [1,4]. pTregs additionally comprise two FoxP3 ${ }^{-}$subsets with important roles in oral tolerance: $\operatorname{Tr} 1$ and Th3 cells [5].

Tregs may exert their suppressive activity via a number of contact-dependent and independent mechanisms, as reviewed extensively [6,7]. Briefly, these include: 
- Suppressive cytokines (TGF- $\beta$, IL-10, IL-35)

- Immune checkpoints and inhibitory receptors (CTLA-4, PD-1, LAG-3, TIM-3, ICOS, TIGIT, IDO)

- Direct cytotoxicity (perforin/granzyme-mediated)

- Metabolic disruption of T effector cell activity (IL-2 consumption)

- Induction of tolerogenic DCs, which promote T cell exhaustion and expansion

Tregs exhibit considerable phenotypic and functional specialization according to tissue localization, disease state, activation and differentiation status [8-11]. These subsets play differing roles in disease and health, and may be endowed with one or more of these suppressive mechanisms $[12,13]$.

\section{Tregs in Cancer}

In cancers, Tregs are able to suppress anti-tumor immune responses and contribute to the development of an immunosuppressive tumor microenvironment (TME), thus promoting immune evasion and cancer progression [14,15].

Tregs have been extensively characterized in the peripheral blood and immune infiltrates of different cancers $[15,16]$. An accumulation of FoxP3 ${ }^{+}$Tregs and, in particular, a higher Treg: $\mathrm{T}$ effector cell (Teff) ratio within tumor tissue is associated with worse prognoses in many cancers, including ovarian cancer [17,18], pancreatic ductal adenocarcinoma [19,20], lung cancer [21], glioblastoma [22], non-Hodgkin's lymphoma [23], melanoma and other malignancies [24,25]. The role of Tregs in immune escape is supported by clinical studies, and numerous in vitro studies, where Treg depletion released anti-tumor immunity. For example, transient Treg depletion induced regression of metastatic lesions in advanced stage melanoma patients [26]. In breast cancer patients undergoing tumor resection and radiotherapy, Treg depletion prior to treatment is associated with an anti-tumor immune response and improved clinical outcomes [27]. Additionally, Treg depletion followed by cancer antigen vaccination generated effective anti-tumor $\mathrm{CD} 4^{+}$and $\mathrm{CD} 8^{+} \mathrm{T}$-cell responses in metastatic breast cancer patients [28] .

It should also be noted that Treg infiltration and accumulation can correlate with a positive prognosis in certain malignancies, including colorectal and gastric cancers [29,30]. In these cancers, Tregs are proposed to play a protective role by controlling inflammation associated with neoplastic transformation and cancer progression. This topic was recently reviewed [31] and will be briefly discussed.

Tregs are able to accumulate within the TME via several mechanisms [32]. These are summarized below:

- Recruitment: Tregs are recruited into tumors in response to chemokines secreted by tumor cells and innate immune cells; key chemokine-chemokine receptor combinations include CCL17/22-CCR4, CCL5-CCR5, CCL28-CCR10 and CXCL9/10/11-CXCR3.

- Expansion: Tregs can be expanded in situ, and proliferate efficiently in response to tumor-derived factors (TGF- $\beta$, IL-10) within the TME.

- Conversion: Generation of suppressive Tregs from non-suppressive CD25- conventional T cells (Tconv) driven by tumor-derived transforming growth factor-beta (TGF- $\beta$ ) and adenosine; this has mainly been studied in murine models and the contribution of Treg induction to Treg accumulation within the TME in human cancer remains to be confirmed.

Further mechanisms of Treg recruitment and generation are still being uncovered. For example, sphingosine 1-phosphate (S1P)—a bioactive lipid mediator involved in angiogenesis and inflammation-is important for immune cell trafficking and is able to restrain Treg development in the periphery [33]. In pre-clinical models, S1P receptor 1 (S1PR1) signaling was necessary for Treg accumulation within the TME, acting via the JAK/STAT-3 signaling pathway [34]. The importance of $\mathrm{S} 1 \mathrm{P} / \mathrm{S} 1 \mathrm{P}$ receptor signaling for the immune response in human cancer remains to be confirmed.

As highlighted by the variable impact of Tregs in different cancers, the role of Tregs in cancer is multi-faceted and is influenced significantly by cancer type, stage and location, in addition to the unique immune landscape and TME of each cancer $[24,25,35,36]$. This review focuses on the role of Tregs as suppressors of anti-tumor immune responses, and specifically on their roles within the TME. 


\subsection{Immunosuppressive Roles of Tumor-Infiltrating Tregs in Cancer}

Tumor-infiltrating (TI) Tregs play direct roles in promoting immune evasion and the development of a pro-tumorigenic TME. They exhibit distinct phenotypic and functional profiles, upregulating markers associated with activation and enhanced suppressive activity. These include immune checkpoint molecules, cytotoxic T-lymphocyte associated protein 4 (CTLA-4), T-cell immunoglobulin and mucin-domain containing-3 (TIM-3/HAVCR2), lymphocyte activation gene-3 (LAG-3), programmed-death 1 (PD-1), inducible T-cell co-stimulator (ICOS), and glucocorticoid-induced TNFR family related gene (GITR); and T cell activation markers, CD25 and CD69 [37-45].

Numerous studies have identified suppressive Treg subsets in the peripheral blood of cancer patients. However, direct insights into the suppressive roles of Tregs within the TME are limited. FoxP3 ${ }^{+/-}$TI Treg subsets isolated from primary tumors of colorectal cancer (CRC) patients exerted a potent suppressive activity mediated by TGF- $\beta$ and IL-10, and also upregulated CTLA-4 and ICOS [44]. In hepatocellular carcinoma (HCC) and pancreatic cancer patients, two distinct FoxP3 ${ }^{+/}-$TI Treg subsets exhibiting differential expression patterns of CTLA-4, PD-1, CD25 and CD69 were identified in tumor-infiltrating lymphocyte (TIL) populations. These TI Tregs suppressed the activity of autologous CD4 ${ }^{+} \mathrm{T}$ cells and gamma delta $(\gamma \delta)$ T cells via secretion of TGF- $\beta$ and IL-10 $[37,46,47]$. In another HCC study, FoxP3 ${ }^{-} \mathrm{CD}_{69}{ }^{+} \mathrm{CTLA}-4^{+} \mathrm{PD}-1^{+}$Tregs were enriched within the TME where they comprised over $60 \%$ of the $\mathrm{CD}^{+}$TIL populations and suppressed autologous Teff via membrane-bound TGF- $\beta$ [43]. FoxP3 ${ }^{+}$ TI Tregs from gastric cancer patients were shown to exert suppressive activity via production of cyclooxygenase-2 (COX-2) and prostaglandin E-2 (PGE-2) [48]. Other groups have isolated highly suppressive FoxP3 ${ }^{+}$Tregs expressing CTLA-4, GITR and TIM-3 from immune infiltrates of HCC, CRC, cervical and ovarian carcinomas $[17,42,49,50]$.

These studies highlight the varied suppressive functionality and phenotype of TI Tregs. A number of the markers expressed on TI Treg subsets are directly involved in suppressive function. Inhibitory immune checkpoint molecules, such as CTLA-4, PD-1, LAG-3 and TIM-3, act to dampen immune responses and prevent excessive $\mathrm{T}$ cell activation during physiological immune responses. CTLA-4 promotes $\mathrm{T}$ cell suppression by preferentially binding with CD80/86 signaling molecules over CD28, effectively blocking CD28 co-stimulatory signals required for T cell activation. Similarly, LAG-3, TIM-3 and PD-1 are inhibitory receptors that negatively regulate Teff and CD8 ${ }^{+}$cytotoxic lymphocyte (CTL) function, as well as potentially promoting Treg generation and function [51,52].

The expression of other functional markers may also imply in vivo suppressive activity of Tregs. Co-expression of GARP/LAP on Tregs infers the presence of membrane-bound latent TGF- $\beta$ complexes. Latency-associated peptide (LAP) sequesters TGF- $\beta$ in inactive latent TGF- $\beta$ complexes, which are anchored to the surface of $\mathrm{T}$ cells by transmembrane glycoprotein A repetitions predominant (GARP) [53,54]. Latent TGF- $\beta$ complexes can be cleaved to release active TGF- $\beta$ in response to a variety of signals. Highly suppressive $\mathrm{LAP}^{+}$and GARP/LAP co-expressing Tregs have been identified in TILs of CRC patients and the peripheral blood of pancreatic, CRC and anti-CTLA-4-treated bladder cancer patients, where their suppressive activity was mediated by TGF- $\beta$ and IL-10 [44,55-57]. Similarly, the ectonucleotidases, CD39/CD73, act synergistically to generate immunosuppressive adenosine from exogenous ATP; a key suppressive pathway within the TME [58,59]. CD39 and CD73 are rarely co-expressed on human Tregs; however, CD39 has been shown to be highly expressed on intra-tumoral Tregs in colon and head \& neck cancers (HNC) [39,59-61]. Interestingly, CD39+ Tregs can interact directly with $\mathrm{CD}^{+} 3^{+}$cells or $\mathrm{CD}^{+} 3^{+}$exosomes derived from the TME to produce adenosine $[60,62]$.

\section{Enhanced Suppression in the TME}

TI Tregs exhibit enhanced suppressive capacity compared to Tregs isolated from peripheral blood and healthy tissue $[39,42,50,63]$. This may in part be due to increased Treg activation within the TME, where Tregs are exposed to tumor-associated antigens (TAA) and neoepitopes [32]. TAAs are derived from self-antigens which Tregs detect with a high affinity compared to Teff, thus enabling their 
preferential activation. Tregs can be divided into three distinct subsets based on their activation and differentiation status, as described by Miyara et al. [8]:

1. CD45RA ${ }^{-}$FoxP3 3 hi activated "effector" Tregs

2. $\mathrm{CD}_{4} 5 \mathrm{RA}^{+} \mathrm{FoxP}^{\mathrm{lo}}$ resting Tregs

3. cytokine-secreting $\mathrm{CD}_{4} 5 \mathrm{RA}^{-}{ }^{-} \mathrm{FoxP}^{\mathrm{lo}}{ }^{\mathrm{o}}$ non-suppressive $\mathrm{T}$ cells, or "non-Tregs"

"Effector" Tregs (eTregs) represent a terminally differentiated and highly suppressive Treg subset. eTregs have been shown to predominate within TIL populations in CRC, lung cancers and melanomas [40,41,45,56]. In CRC patients, it has recently been shown that tumor infiltration by FoxP3 ${ }^{\text {hi }}$ eTregs was associated with poorer prognosis, compared to tumors infiltrated by non-suppressive FoxP3 $3^{\text {lo }} \mathrm{T}$ cells [64]. Depletion of circulating CCR4 ${ }^{+}$eTregs by an anti-CCR4 mAb restored antigen-specific CTL responses in an adult T-cell leukemia-lymphoma patient [41]. Activated Tregs have also been shown to upregulate expression of functionally suppressive molecules (GARP/LAP, CD39/CD73) and immune checkpoints (CTLA-4, TIM-3, GITR, PD-1, LAG-3), thus potentiating greater suppressive activity.

The selective accumulation of eTregs within tumor tissue, but not peripheral blood, suggests eTregs are preferentially recruited and/or activated within the TME $[40,41,45,56]$. The exact mechanism by which highly suppressive and activated eTregs might accumulate within the TME is still an open question and may vary by cancer, although it likely involves chemotactic migration. As studied extensively, Tregs isolated from healthy donors and cancer patients can express a plethora of chemokine receptors (CCR2-9, CXCR3/4) and migrate efficiently in vitro in response to tumor-derived chemokines, typically secreted by cancer cells or innate immune cells [32,45,65]. The CCL17/22-CCR4 axis has been shown to be particularly important in lymphomas, lung, breast, ovarian, gastric and prostate cancers [32,65]. Additionally, Tregs have been reported to proliferate efficiently in vivo in the peripheral blood and particularly within the tumor tissues of CRC and metastatic prostate cancer patients $[44,66]$. In CRC, a greater proportion of CD25 $5^{+} \mathrm{FoxP}^{+}$TI Tregs expressed Ki67, compared with Tregs from tumor-free liver and peripheral blood, indicating efficient in situ proliferation [42]. In comparison, Tregs isolated from tumor tissue, tumor-free liver and peripheral blood of HCC patients all expressed significantly lower levels of Ki67 than TI Tregs from CRC patients [42]. This again highlights the differences in Treg biology in different cancers.

Understanding the most relevant Treg mechanisms or markers within the TME is important for designing Treg-targeted immunotherapies. For example, CCR4-targetted antibodies (Abs) have shown promising results, inducing effective depletion of FoxP3 ${ }^{+}$Tregs both in vitro and in vivo [41,45,67-70].

\subsection{TME-Treg Crosstalk}

The TME is a critical contributing factor to immune evasion and the efficacy of immunotherapeutic approaches in cancer. Tumor cells, tumor-infiltrating immune cells, stromal cells, and other infiltrating cell subsets work in concert to establish a TME that is tolerogenic, hypoxic, rich in pro-angiogenic growth factors and highly immunosuppressive [71,72]. Cell-cell crosstalk is important for normal physiological function and maintenance of homeostasis. In cancer, Tregs interact with infiltrating immune cell subsets, stromal cells and tumor cells within the TME to enhance Treg generation and suppressive function, as recently reviewed [73]. Herein, we briefly summarize the interactions between Tregs and different components of the TME.

Natural Killer (NK) cells: Studies of NK cell-Treg interactions in human cancer are limited [74]. Circulating Tregs isolated from healthy donors and gastrointestinal stromal tumor patients are able to suppress NK cells via membrane-bound TGF- $\beta$, downregulating expression of the activating NK cell receptor (NKG2D) [75]. Similar findings were reported in cervical carcinomas where TI and circulating Tregs potently suppressed NK cell activity in vitro [76].

Myeloid-derived Suppressor cells (MDSCs): MDSCs are immunosuppressive cells that are critical to promoting tumor-immune evasion, in collaboration with Tregs [77,78]. Both Tregs and MDSCs are able 
to induce generation and enhance the suppressive activity of the other via various signaling pathways, including inhibitory programmed death ligand-1 (PD-L1/B7-H1) signaling [79,80]. Their interactions in cancer have recently been reviewed in detail [73,81].

Antigen-presenting cells (APCs): Similar to other lymphocytes, Tregs rely on APCs such as dendritic cells (DCs) and macrophages for antigen presentation and T cell activation. DCs and Tregs exhibit extensive bi-directional cross-talk, influencing the immune response both in physiological and pathological settings. Within the TME, naïve tolerogenic DCs and plasmacytoid dendritic cells (pDCs) promote Treg function and generation $[82,83]$. Through a number of mechanisms-including production of TGF- $\beta$ and IL-10, and upregulation of inhibitory B7-H3/4 molecules on DCs-Tregs are able to influence DC maturation, directing them towards a tolerogenic phenotype and impairing their ability to activate Teff and CTLs.

Stromal cells: The stroma is intimately involved in cancer initiation, progression and metastasis. However, Treg-stromal interactions in humans are not well understood. Initial in vitro work suggests that stromal cells may be important in recruiting and generating Tregs at tumor sites, possibly through cell contact-dependent mechanisms and secretion of soluble mediators including TGF- $\beta$, PGE- 2 , and indoleamine 2,3-dioxygenase (IDO) [84].

Endothelial cells (ECS): ECs and lymphatic endothelial cells (LECs) typically come into contact with antigens, cytokine and migrating immune cells at an early stage, and play important roles in controlling the immune response and immune cell trafficking. ECs have been shown to enhance Treg migration, and to induce Treg generation under inflammatory conditions [85-87]. Tregs are also able to interact with ECs to restrain Teff migration, by impairing EC selectin expression and adhesion to Teff [88].

Tumor angiogenesis: Tumor angiogenesis is a key step in cancer development and progression, driven by pro-angiogenic growth factors such as vascular endothelial growth factor-A (VEGF-A). Intra-tumoral accumulation of $\mathrm{FoxP}^{+}$Tregs is associated with increased tumor vasculature density in endometrial cancers [89]. In an in vitro model of ovarian cancer, Tregs conditioned under hypoxic conditions, similar to the in vivo TME, secreted significantly higher levels of VEGF-A compared to normoxic conditions and efficiently induced endothelial-tube formation in vitro [90].

Tumor-derived exosomes (TEX): TEX are a newly identified mechanism by which tumor cells may enhance Treg function. TEX deliver tumor-derived factors which enhance Treg suppressive activity, lineage stability and resistance to apoptosis [60,91]. Interestingly, TEX have also been shown to modulate adenosine pathway-related gene expression in Tregs, potentially promoting deaminase activity [91].

\subsection{Protective Role of Tregs in Inflammation/Cancer}

Recent studies show that an intra-tumoral accumulation of $\mathrm{FoxP}^{+}$Tregs is associated with positive prognoses in certain malignancies, including CRC, HNC, and esophageal cancers [25,31]. In these cancers, Tregs are proposed to play protective roles by controlling tumor-promoting inflammation $[31,92,93]$.

Inflammation contributes both to cancer initiation and progression by promoting genomic instability, neoplastic transformation, tumor metastasis, tumor angiogenesis, and survival and proliferation of malignant cancer cells [94]. Inflammation has been linked to increased incidence of malignancies of the gut, airway and mucosal interfaces; these are "inflammation-prone" sites which are continually exposed to microbial and foreign antigen challenge and are particularly sensitive to perturbations in immune homeostasis or local microbiota $[36,95]$. The initial inflammatory insult contributing to neoplastic transformation may have different sources: (i) chronic viral infections such as human papilloma virus (HPV) in head and neck cancers, or hepatitis B/C virus (HBV/HCV) in HCC; (ii) exposure to tobacco and other carcinogens in lung cancers; or (iii) increased penetration of the mucosal barrier by commensal bacteria prior to development of CRC [36]. Tregs are critical to maintaining tolerance in the airways and at gut and mucosal interfaces $[1,5,96]$. Given the link 
between inflammation and cancer, it is feasible that Tregs play protective roles prior to cancer initiation in "inflammation-prone" cancers [97].

There are a number of open questions with regards the protective role of Tregs in cancer. Are the Treg subsets involved in inhibiting anti-tumor immunity distinct from those involved in controlling potentially tumorigenic inflammation? Following tumor establishment, can "protective Tregs" be co-opted by tumors and undergo a switch to a pro-tumorigenic role? For example, Tr1 cells, critical mediators of oral tolerance, have been shown to accumulate in the peripheral blood of HNC patients with advanced disease stage and in patients showing no sign of active disease following successful therapy [98]. An accumulation of highly suppressive and activated FoxP3+ TI Tregs in the tumor tissue of CRC patients has also been reported to correlate with tumor progression $[40,99]$.

It should be noted that the majority of clinical studies currently utilize FoxP3 and CD25 as Treg markers. While FoxP3 ${ }^{+} \mathrm{CD} 25^{\text {hi }} \mathrm{T}$ cells include significant populations of suppressive Tregs, both CD25 and FoxP3 can be highly upregulated on non-suppressive T cells during activation or inflammation $[100,101]$. It is critical that the suppressive lineage of lymphocytes identified as Tregs is confirmed either functionally in suppression assays or by utilizing Treg markers relevant to the tissue context [102]. A number of reviews discussing the role of Tregs in colorectal cancer have highlighted this issue [31,58].

\subsection{Treg Subsets and Heterogeneity}

Tregs comprise diverse and heterogeneous subsets displaying tissue- and disease-specific phenotypic and functional features. Defining the different subsets and understanding their roles in immune evasion is crucial for designing effective immunotherapies. Herein, we briefly describe the different Treg subsets.

pTregs and tTregs: The exact composition of TI Treg subsets has been a subject of debate, focusing mainly on FoxP3-expressing tTregs and pTregs [92,103]. Efforts to define the specific roles of pTregs and tTregs in cancer have been hindered in part due to the lack of effective Treg markers. Neuropilin 1 (NRP1) and the Ikaros zinc finger transcription factor, Helios, enable identification of tTregs and extra-thymically induced pTregs in mice but not in humans, although they can be expressed on highly suppressive Treg subsets $[16,57,92,103,104]$. Helios, in particular, may represent an important Treg marker although its exact role in human Tregs remains to be confirmed [57].

$\operatorname{Tr} 1$ cells: Highly suppressive $\operatorname{Tr} 1$ cells have been characterized in Hodgkin's lymphoma, head and neck squamous cell carcinoma (HNSCC), HCC and CRC $[44,83,98,105]$. Tr1 cell generation from naive $\mathrm{CD} 4^{+} \mathrm{T}$ cell precursors is promoted at tumor sites mainly through the action of immature DCs or tolerogenic pDCs, as shown by in vitro models of HNSCC, HCC and liver metastases of CRC [83,98]. In a CRC study, Tr1 cells were shown to comprise up to $30 \%$ of the tumor-infiltrating lymphocyte subsets [44]. These TI Tr1 cells produced IL-10 and TGF- $\beta$, and exhibited an in vitro suppressive activity up to 50 times more potent than autologous $\mathrm{FoxP}^{+}$Tregs [44]. Although $\operatorname{Tr} 1$ cells represent a highly suppressive Treg subset, their clinical impact in cancer is still uncertain. An increase in the Tr1 cell : FoxP3 ${ }^{+}$tTreg ratio was associated with longer survival in a small clinical study of four recurrent ovarian cancer patients undergoing adoptive T cell transfer with autologous IL-10 and interferon gamma (IFN- $\gamma$ )-producing Teff [106].

Th3 cells: Similar to Tr1 cells, Th3 cells are important for maintaining oral tolerance. While they have been studied to a certain extent in murine models, their contribution and relevance to human cancers is not clear [5].

Interestingly, Tregs are also able to partially co-opt the transcriptional profile of Thelper (Th) cell subsets in order to home into specific sites within the body while maintaining their suppressive lineage $[9,107]$. This is thought to occur in response to inflammatory or environmental signals. For example, in an ovarian carcinoma study, the majority of FoxP3 ${ }^{+}$TI Tregs upregulated the Th1 master transcription factor, T-bet, and expressed CXCR3 enabling them to migrate in response to CXCL10 [108]. These FoxP3 ${ }^{+}$CXCR3 ${ }^{+}$were suppressive ex vivo, co-expressed Helios and, intriguingly, 
their numbers matched those of $\mathrm{CXCR}^{+}$Th1 cells, suggesting both may have been recruited into the TME down a similar CXCL10 chemotactic gradient. In addition to these subsets, specialized tissue-resident Tregs can also be recruited by tumors, although their exact contribution to tumor immunity is not known [93].

\subsection{Antigen Specificity of Tregs}

Tumors are thought to present neo-epitopes that may preferentially activate Tregs and promote tumor-specific immune suppression within the TME [109,110]. Antigen (Ag)-specific Tregs have been isolated from the peripheral blood and TILs of CRC, pancreatic cancer, bladder cancer, melanoma and other cancers [46,99,111-113]. Suppressive Ag-specific Tregs have also been induced in vitro and in vivo in melanoma patients following peptide stimulation or immunization $[111,112]$. In pancreatic cancer patients, FoxP $3^{+}$IL- $10^{+}$TGF- $\beta^{+}$TI Tregs comprised $12 \%$ of the ENO1-specific CD $4^{+}$ $\mathrm{T}$ cell population and specifically inhibited the proliferation of autologous ENO1-specific Teff [46]. ENO1-specific Tregs were able to interact with ENO1 at significantly lower concentrations of antigen than ENO1-specific Teff, suggesting that the Ag-specific Treg TCR had a higher affinity for ENO1 [46]. In CRC patients undergoing resection, the presence of suppressive Tregs specific for the CRC-associated antigens, CEA and 5T4, was correlated with tumor recurrence and relapse [99]. A recent bladder carcinoma study identified a number of TAAs that Tregs were specific for; interestingly, Teff specific for the same TAAs did not co-occur in these patients [113]. Similarly, in ovarian cancer, Tregs were shown to co-exist with NY-ESO-1-specific Teff within tumor tissue, but were not specific for NY-ESO-1 [114].

The full extent and relevance of Ag-specific Treg responses to clinical outcomes is not yet clear. Tregs are able to exert non-specific "bystander tolerance" following in vitro stimulation. Further studies are required to confirm the importance of Treg Ag specificity in immune evasion.

\subsection{Tregs by Cancer Stage}

Tregs have been studied extensively in established tumors where an accumulation of functionally suppressive Tregs tends to correlate with advancing tumor stage, and is accompanied by concomitant Teff and CTL impairment. The immune landscape within tumors, however, varies greatly by stage and the contribution of Tregs during other phases of cancer progression is less clear [115]. Herein, we briefly discuss possible roles of Tregs during cancer initiation and establishment, metastasis, remission and recurrence.

\subsubsection{Cancer Initiation and Establishment}

During early neoplastic events, innate immune cells are typically "first on the scene". In response to chemokines secreted by tumor cells and innate immune cells, Tregs are recruited to cancerous lesions or tumor-draining lymph nodes (TDLN) where they are chronically exposed to and activated by TAAs and tumor-derived factors [116,117]. The net result is an accumulation of suppressive Tregs in TDLN and tumor tissue compared to functional Teff and CTLs. As discussed earlier, these activated TI Tregs downregulate the anti-tumor activity of Teff, CTLs, NK cells and DCs, and secrete immunosuppressive molecules, setting the scene for tumor progression and growth. The question remains-how critical are Tregs to the initiation and establishment of cancers along with MDSCs, macrophages, mast cells and other innate immune cells? Do perturbations in immune homeostasis contribute to neoplastic transformation? In inflammation-associated cancers, the contribution is clear. However, in other malignancies, the exact role of the immune system likely depends on specific tumor "immunogenicity" and immunobiology.

The role of Tregs in the early immune response to cancer has primarily been investigated in murine studies, given the technical difficulties with studying Treg biology prior to cancer detection in humans [118]. Interesting parallels have been drawn between the early immune response, and subsequent induction of immune tolerance, in human pregnancy and cancer [118]. The immune privilege offered to developing neoplasms by Tregs may mirror that of a developing embryo, 
representing a highly effective and evolutionarily conserved immune tolerance mechanism that is co-opted by tumors for their own benefit. An exception to this model, as noted earlier, may be at gut, airway and mucosal interfaces where Tregs are thought to play a protective role, controlling cancer-associated inflammation.

\subsubsection{Tumor Metastasis}

The potential roles of Tregs in promoting and establishing metastatic sites were discussed in an extensive review [119]. Tregs have been shown to infiltrate metastatic sites in various cancers, where they often also predict worse outcomes. At these metastatic sites, Tregs are proposed to play similar roles as within the TME, promoting immune tolerance and immune evasion. A number of questions remain unanswered in humans; do Tregs contribute directly to "conditioning" of pre-metastatic niches? Which mechanisms of Treg recruitment and suppression are most relevant for metastases?

Pre-clinical murine models show that Tregs are important for establishing metastatic sites following dissemination of tumor cells, highlighting in particular the role of receptor activator of nuclear factor kappa-B ligand (RANKL) on Tregs in directly promoting RANK $^{+}$breast cancer invasion [120]. Intriguingly, human CD25+CD127 ${ }^{\text {lo }}$ Tregs isolated from the peripheral blood of HCC patients were recently shown to enhance proliferation of the HepG2 cell line in vitro via upregulation of the RANK-RANKL pathway [121]. Further investigations into the mechanisms of Treg recruitment and their roles at metastatic sites are warranted.

\subsubsection{Remission/Recurrence}

As discussed earlier, the critical suppressive role of Tregs in inhibiting anti-tumor immune responses in many cancers is now well-accepted. A natural follow-on question is whether Tregs are directly involved in mediating tumor recurrence or remission. The presence of suppressive Tregs prior to resection, chemotherapies or radiotherapies has been shown to predict tumor recurrence and worse clinical outcomes; whether this link indicates a causal or correlative relationship, however, is not clear and must be confirmed in vivo [122]. Tumors often display a "T cell inflamed" phenotype characterized by significant $\mathrm{T}$ cell infiltration and reliance on immunosuppressive networks (Tregs, IDO, adenosine) to evade anti-tumor immune responses; in these tumors, Tregs might play a more central role in promoting tumor remission or recurrence [123]. In contrast, "non-T cell inflamed" tumors exclude immune cells, have denser stroma and are often infiltrated by immunosuppressive MDSCs [123].

\section{Clinical Evidence for Treg Therapeutic Targeting}

Given their roles in promoting tumor progression and immune escape, Tregs offer promising therapeutic targets. A number of approaches have been developed and are currently in development to deplete Tregs or impair their suppressive functionality [122,124], as shown in Table 1/Figure 1.

Table 1. Therapeutic modalities for targeting Tregs (reviewed in [124]).

\begin{tabular}{ll}
\hline Therapy & Modality \\
\hline Low-dose chemotherapy & Treg depletion \\
CD25-targetted Abs & Treg depletion \\
Immune checkpoint inhibition (ICI) & Functional targeting + Treg depletion \\
Chemokine receptor blockade & Functional targeting + Treg depletion \\
Blockade of suppressive mechanisms \& soluble mediators (IL-10/TGF- $\beta$ ) & Functional targeting \\
\hline
\end{tabular}

The effect of chemotherapy on Tregs is fairly well-established; low-dose metronomic cyclophosphamide (CTX) can reduce levels of Tregs within TME, TDLN and peripheral blood $[125,126]$. Treg depletion by low-dose chemotherapy or CD25 blockade prior to adoptive cell therapies, cancer vaccination or other treatment modalities significantly enhances patient survival and development 
of an effective anti-tumor immune response, as reported in different human cancers $[27,28,127,128]$. We will focus here on the impact and utility of immune checkpoint inhibition and chemo/radiotherapies for targeting Tregs.

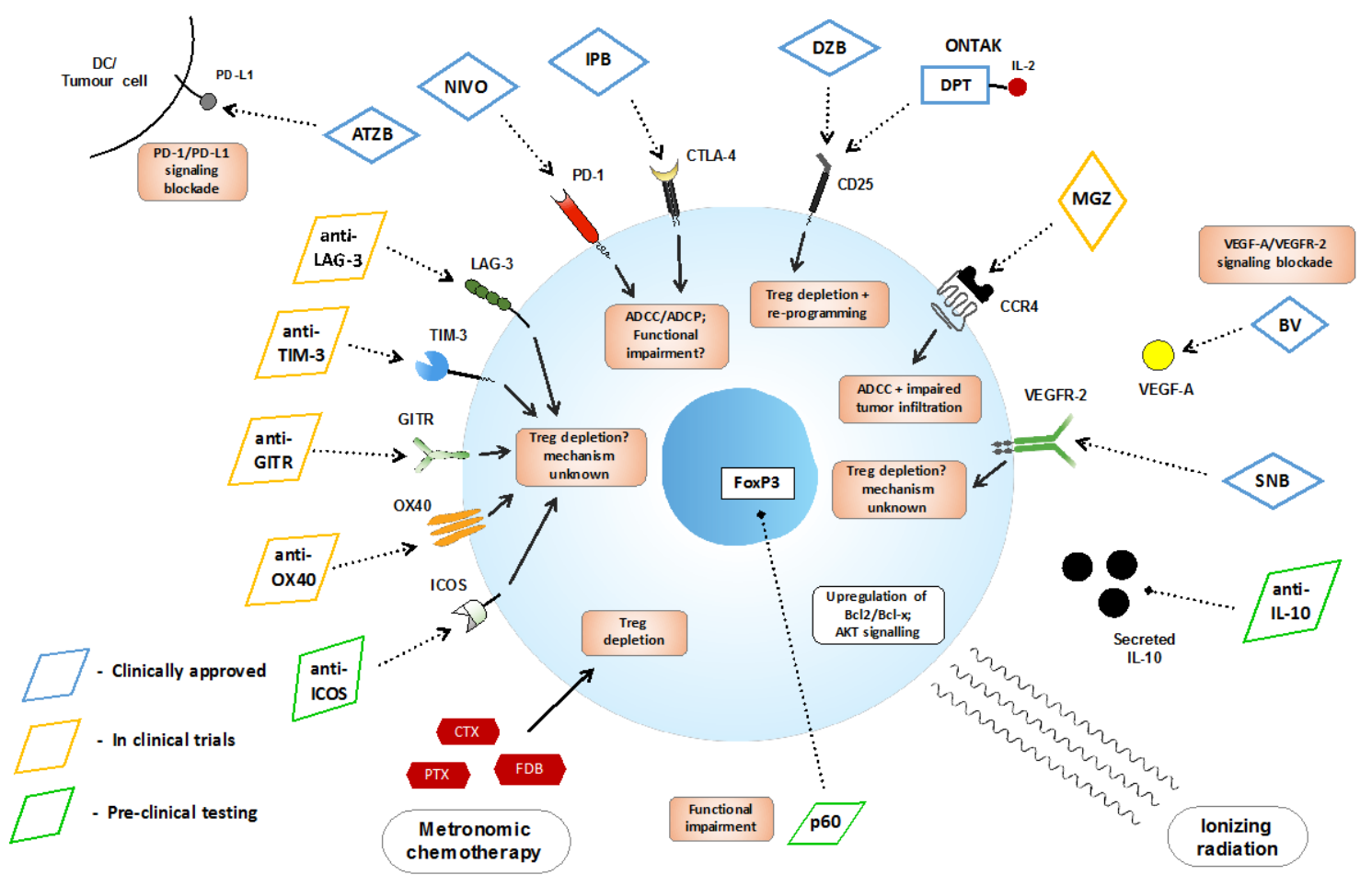

Figure 1. Summary of currently approved and experimental therapies that may target Tregs; therapies are color-coded according to stage in clinical testing. Abbreviations-ADCC: antibody-dependent cell-mediated cytotoxicity, ADCP: antibody-dependent cellular phagocytosis, ATZB: atezolizumab, BV: bevacizumab, CTX: cyclophosphamide, DC: dendritic cell, DZB: daclizumab, CCR4: C-C motif chemokine receptor 4, DPT: diptheria toxin, FDB: fludarabine, IPB: ipilimumab, MGZ: mogamulizumab, NIVO: nivolumab, ONTAK: denileukin difitox, PTX: paclitaxel, SNB: sunitinib.

\subsection{Immune Checkpoint Inhibition and Tregs}

Immune checkpoint inhibitors (ICI) for cancer treatment aim to re-establish anti-tumor immune responses by blocking inhibitory immune checkpoint molecules or their ligands, which are often over-expressed on intra-tumoral lymphocyte populations and tumor tissues [52]. ICI strategies have seen significant successes in pre-clinical and clinical trials of non-small cell lung cancers (NSCLC), RCC and melanoma, inducing tumor regression and remission-free survival, although responses are limited to $10 \%-20 \%$ of patients [129-132]. Monoclonal antibodies (mAbs) against CTLA-4 (ipilimumab) and PD-1 (nivolumab/pembrolizumab) have been approved by the FDA for the treatment of metastatic melanoma, NSCLC, advanced RCC and Hodgkin's lymphoma.

Despite clinical successes to-date, the exact mechanisms of action of ICI are not fully understood. ICI strategies were initially developed to enhance Teff and CTL functionality. However, it is becoming apparent that ICI might also impact other aspects of the immune system, including depleting or functionally impairing Tregs. As discussed earlier, tumor-infiltrating Tregs highly upregulate expression of various immune checkpoint molecules (CTLA-4, PD-1, LAG-3, TIM-3, GITR), making them viable targets for ICI. 


\subsubsection{Anti-CTLA-4}

The primary proposed mechanism of action of anti-CTLA- 4 mAbs is via promotion of T-cell proliferation and activation, due to blockade of CTLA-4/CD28 interactions. Ipilimumab and tremelimumab are two well-characterized IgG1 and IgG2 anti-CTLA-4 mAbs, respectively. Numerous studies report that treatment with ipilimumab or tremelimumab, as monotherapies or in combination with other treatment regimens, induces significant expansion and activation of Teff and CTLs [66,133-141]. Interestingly, FoxP3 ${ }^{+}$Tregs have been shown to be stably maintained or increased in the peripheral blood or TILs of cancer patients treated with ipilimumab (Table 2) or tremelimumab (Table 3).

In metastatic prostate cancer and advanced melanoma patients, ipilimumab treatment induced a significant increase in Ag-specific humoral and CTL responses, while levels of suppressive FoxP3 ${ }^{+}$ Tregs remained stable or were expanded $[66,139,141]$. Similarly, in advanced melanoma or RCC patients, treatment with tremelimumab induced broad expansion and activation of $\mathrm{CD} 4^{+}$and $\mathrm{CD} 8^{+} \mathrm{T}$ cell subsets, including suppressive Tregs [133]. These studies suggest that CTLA-4 blockade expands and activates Tregs in a similar manner to CTLs and Teff, without affecting their suppressive activity. Indeed, in ipilimumab-treated metastatic prostate cancer patients, almost $50 \%$ of circulating $\mathrm{FoxP}^{+}$ Tregs expressed the proliferation marker Ki67 indicating they were proliferating efficiently in vivo [66]. This raises an interesting question regarding ICI and the role of CTLA-4 on Tregs: how can ICI induce tumor regression and anti-tumor immune responses, if both Tregs and Teff are expanded and activated during treatment?

Pre-clinical murine models have shown that, in conjunction with activating Teff and CTLs, anti-CTLA-4 mAbs exert anti-tumor activity via antibody-dependent cell-mediated cytotoxicity (ADCC)-mediated depletion of intra-tumoral Tregs [142,143]. This has recently been reported in human studies [144,145]. Ipilimumab was required for NK cell-mediated ADCC and in vitro depletion of CTLA $-4^{+}$TI Tregs isolated from TILs of HNSCC patients [144]. Similarly, in a clinical study of melanoma patients, ipilimumab was required for Fc gamma receptor III (Fc $\gamma$ RIII)-expressing non-classical monocytes to mediate ADCC of Tregs in vitro [145]. Interestingly, metastatic lesions of melanoma patients who responded to ipilimumab were enriched for Fc $\gamma$ RIII-expressing CD68 ${ }^{+}$ "inflammatory" macrophages prior to treatment, while intra-tumoral FoxP3 ${ }^{+}$Tregs were depleted following treatment. These preliminary data suggest that ADCC-mediated Treg depletion, and the presence of innate immune cells to mediate ADCC, are important for ICI activity.

An important point to consider is that the immune profile of the peripheral blood does not accurately reflect the TME, and has varying utility as a prognostic factor. In contrast, the make-up of the TME is directly relevant to clinical outcomes. Perhaps the TME of clinical responders is enriched both for CTLA $-4^{+}$Tregs and Fc $\gamma$ RIII-expressing innate immune cells or NK cells. This promotes ADCC-mediated Treg depletion and re-establishment of an anti-tumor immune response following CTLA-4 blockade. Tregs constitutively express CTLA-4, both intra-cellularly and on their surface. The enhanced expression of CTLA-4 may make Tregs more prone to ADCC, and might also explain why Teff and CTLs are not depleted during CTLA-4 blockade.

Tremlimumab, as an IgG2 isotype mAb, is less likely to form immune complexes and induce ADCC compared with ipilimumab, an IgG1 isotype mAb. However, tremelimumab is able to abrogate the suppressive activity of healthy donor Tregs in vitro $[138,146]$. Treatment with tremelimumab in advanced melanoma patients can selectively confer to PBMCs resistance against Treg-mediated inhibition in in vitro suppression assays. Following treatment, circulating Tregs remained functionally suppressive, and generation of Treg resistance was associated with improved progression-free survival [135]. 
Table 2. Clinical studies investigating the impact of ipilimumab on Tregs.

\begin{tabular}{|c|c|c|c|c|c|c|}
\hline Cancer & Treg Markers & PB/TILs & Functional Analysis & Expanded? & Survival & Ref. \\
\hline $\begin{array}{l}\text { Resected stage IIIc/IV } \\
\text { melanoma }(n=75)\end{array}$ & $\mathrm{CD} 25^{+}$ & РВ & $\begin{array}{c}\text { Suppressive; no effect after } \\
\text { treatment }\end{array}$ & No change & $\mathrm{N} / \mathrm{A}$ & [147] \\
\hline $\begin{array}{l}\text { Unresectable stage III/IV } \\
\text { melanoma }(n=80)\end{array}$ & $\mathrm{CD} 25^{\text {hi }} \mathrm{CD} 127^{\mathrm{lo}} \mathrm{FoxP}^{+}$ & РB & $\mathrm{N} / \mathrm{A}$ & No change at weeks 4 \& 12 & $\mathrm{~N} / \mathrm{A}$ & [139] \\
\hline Stage IV malignant melanoma & $\mathrm{CD}_{25^{+}} \mathrm{FoxP}^{+}$ & PB & $\mathrm{N} / \mathrm{A}$ & Decreased & No statistical link & [148] \\
\hline $\begin{array}{l}\text { Bladder cancer patients prior } \\
\text { to radical cystectomy }(n=6)\end{array}$ & $\mathrm{CD}_{25^{+} \mathrm{FoxP}^{+}}^{+}$ & PB & $\begin{array}{c}\text { Suppressive } \\
\text { pre/post-treatment }\end{array}$ & $\begin{array}{l}\text { Overall decrease; variable } \\
\text { initial response }\end{array}$ & $\mathrm{N} / \mathrm{A}$ & [149] \\
\hline $\begin{array}{l}\text { Bladder cancer patients prior } \\
\text { to radical cystectomy }(n=6)\end{array}$ & $\mathrm{CD}_{25^{+}} \mathrm{FoxP}^{+}$ & TILs & NA & $\begin{array}{l}\text { Increase in ICOS+ Teff : } \\
\text { FoxP3+ Treg ratio }\end{array}$ & $\mathrm{N} / \mathrm{A}$ & [149] \\
\hline Bladder cancer $(n=12)$ & $\mathrm{CD}_{25}{ }^{+} \mathrm{LAP}^{+} / \mathrm{FoxP}^{+} / \mathrm{CD} 127^{\mathrm{lo}}$ & PB & $\begin{array}{c}\mathrm{CD} 25^{+} \mathrm{LAP}^{+}, \text {but not } \\
\mathrm{CD} 25^{+} \mathrm{CD} 127^{\mathrm{lo}} \\
\text { suppressive post-treatment }\end{array}$ & $\begin{array}{l}\mathrm{CD}^{+} 5^{+} \mathrm{LAP}^{+} \text {increased in } \\
\text { patient subset }\end{array}$ & $\mathrm{N} / \mathrm{A}$ & {$[55]$} \\
\hline $\begin{array}{c}\text { Metastatic RCC or metastatic } \\
\text { melanoma }(n=10)\end{array}$ & $\mathrm{CD}_{25^{+}} \mathrm{FoxP}^{+}$ & РB & $\begin{array}{c}\text { Suppressive } \\
\text { pre/post-treatment }\end{array}$ & $\begin{array}{l}\text { No change; increase in } \\
\text { activated T cells }\end{array}$ & $\mathrm{N} / \mathrm{A}$ & [133] \\
\hline $\begin{array}{c}\text { Progressive metastatic } \\
\text { hormone-refractory prostate } \\
\text { cancer }(n=24)\end{array}$ & $\mathrm{CD} 127^{\mathrm{lo}} \mathrm{CD} 25^{\mathrm{hi}}$ & РB & Suppressive post-treatment & Increased, and Ki67 ${ }^{+}$ & $\begin{array}{l}\text { N/A (study* } \\
\text { ongoing) }\end{array}$ & {$[66]$} \\
\hline Stage III/IV melanoma $(n=37)$ & $\mathrm{CD} 25^{\mathrm{HI}}$ Foxp3 & $\mathrm{PB}$ & $\mathrm{N} / \mathrm{A}$ & $\begin{array}{l}\text { Increased at } 6 \text { weeks } \\
\text { post-treatment }\end{array}$ & $\begin{array}{l}\text { Associated with } \\
\text { improved PFS }\end{array}$ & [141] \\
\hline Stage III/IV melanoma $(n=10)$ & $\mathrm{CD} 25^{\mathrm{HI}}$ Foxp3 & TILs & $\mathrm{N} / \mathrm{A}$ & Variable & $\begin{array}{l}\text { Inverse trend between } \\
\text { Treg \& clinical benefit }\end{array}$ & [141] \\
\hline Stage IV melanoma $(n=82)$ & $\mathrm{CD} 127^{\mathrm{lo}} \mathrm{CD} 25^{+} \mathrm{FoxP}^{+}$ & PB & $\mathrm{N} / \mathrm{A}$ & $\begin{array}{l}\text { Increased over } 14 \text { weeks } \\
\text { of treatment }\end{array}$ & $\begin{array}{l}\text { Higher than median } \\
\text { Tregs associated with } \\
\text { better survival }\end{array}$ & [150] \\
\hline
\end{tabular}

All studies utilized CD4 as a T cell marker and dosage is 1-10 mg/kg; N/A: Not investigated; RCC: renal cell carcinoma; PB: peripheral blood; TILs: tumor-infiltrating lymphocytes; * Clinical trial identifier: NCT00064129. 
Table 3. Clinical studies investigating the impact of tremelimumab on Tregs.

\begin{tabular}{|c|c|c|c|c|c|c|}
\hline Cancer & Treg marker & PB/TILs & Functional Analysis & Expanded? & Survival & Ref. \\
\hline DTIC-treated stage IV melanoma $(n=10)$ & $\begin{array}{l}\mathrm{CD}_{25}^{+} \mathrm{CD} 127^{-} \text {or } \\
\text { FoxP3 }^{+}\end{array}$ & PB & $\begin{array}{l}\text { Suppressive pre-treatment; } \\
\text { transient resistance to Treg } \\
\text { suppression post-treatment }\end{array}$ & $\begin{array}{l}\text { Increase in absolute Treg } \\
\text { count, but not proportion }\end{array}$ & $\begin{array}{l}\text { Treatment-induced transient } \\
\text { Treg resistance associated } \\
\text { with better survival }\end{array}$ & {$[135]$} \\
\hline $\begin{array}{l}\text { Stage III/IV melanoma, combined with } \\
\text { IFN- } \alpha 2 \mathrm{~b}(n=37)\end{array}$ & $\begin{array}{l}\mathrm{CD} 25^{\mathrm{hi}} \mathrm{FoxP}^{+} \text {or } \\
\mathrm{CD} 25^{\mathrm{hi}} \mathrm{CD} 39^{+}\end{array}$ & PB & N/A & Both subsets Increased & $\mathrm{N} / \mathrm{A}$ & {$[140]$} \\
\hline Metastatic melanoma $(n=7)$ & $\mathrm{CD}_{25}{ }^{+} \mathrm{FoxP}^{+}$ & TILs & $\mathrm{N} / \mathrm{A}$ & Variable & $\mathrm{N} / \mathrm{A}$ & {$[136]$} \\
\hline
\end{tabular}

All studies utilized CD4 as a T cell marker unless state otherwise; dosage is 1-15 mg/kg; N/A: Not investigated; IFN- $\alpha 2 \mathrm{~b}$ : interferon alfa $2 \mathrm{~b}$ anti-viral drug; PB: peripheral blood; TILs:

tumor-infiltrating lymphocytes. 


\subsubsection{Anti-PD-1}

PD-1 is highly upregulated on "exhausted" T cells, inhibiting T cell proliferation, IFN- $\gamma$ and IL-2 production [52]. The primary effect of PD-1 blockade is reversal of T cell "exhaustion". In vitro assays show that nivolumab is able to abrogate Treg suppressive function although it is not clear whether PD-1 blockade acts directly on Tregs or via activation of Teff [151,152]. Nivolumab promoted CTL proliferation and resistance to Treg-mediated suppression, and also impaired Treg suppressive activity, possibly by downregulating intracellular expression of FoxP3 [151]. In metastatic melanoma, combination treatment of nivolumab with a therapeutic peptide vaccine expanded Tregs in the peripheral blood of non-responders. In clinical responders, however, Tregs were depleted over a 12-week treatment period $[153,154]$. Clinical studies investigating the impact of PD-1 blockade on Tregs are limited (Table 4).

Table 4. Clinical studies investigating the impact of nivolumab on Tregs.

\begin{tabular}{|c|c|c|c|c|c|c|}
\hline Cancer & Treg Markers & PB/TILs & $\begin{array}{l}\text { Functional } \\
\text { Analysis }\end{array}$ & Expanded? & Survival & Ref. \\
\hline $\begin{array}{l}\text { Unresectable stage III/IV } \\
\text { melanoma }(n=90) ; \\
\text { IPB-naive }(n=34) \text { or } \\
\text { IPB-refractory }(n=56)\end{array}$ & $\mathrm{CD}_{25}{ }^{+} \mathrm{CD} 127^{\mathrm{lo}} \mathrm{FoxP}^{+}$ & PB & $\mathrm{N} / \mathrm{A}$ & $\begin{array}{l}\text { Decreased in } \\
\text { responders \& stable } \\
\text { patients; increased in } \\
\text { non-responders }\end{array}$ & $\begin{array}{l}\text { Increased Tregs } \\
\text { associated with } \\
\text { progression at } 12 \text { weeks }\end{array}$ & [153] \\
\hline $\begin{array}{l}\text { Stage IIIc/IV melanoma } \\
(n=33)\end{array}$ & $\mathrm{CD} 127^{\mathrm{lo}} \mathrm{FoxP}^{+}$ & $\mathrm{PB}$ & $\mathrm{N} / \mathrm{A}$ & $\begin{array}{l}\text { Expanded in PB at } \\
12 \& 24 \text { weeks }\end{array}$ & $\begin{array}{l}\text { Trend towards lower } \\
\text { Tregs in non-relapsing } \\
\text { patients }\end{array}$ & [154] \\
\hline
\end{tabular}

All studies utilized CD4 as a T cell marker; dosage is $1-10 \mathrm{mg} / \mathrm{kg}$; N/A: Not investigated; IPB: Ipilimumab; PB: peripheral blood; TILs: tumor-infiltrating lymphocytes.

mAbs targeting other immune checkpoints are currently in development or clinical testing, including combination therapies with ipilimumab and nivolumab $[129,155,156]$. Other targets include the stimulatory immune checkpoints (GITR, OX-40, 4-1BB) and inhibitory immune checkpoints (LAG-3, TIM-3).

\subsection{Effect of Radiotherapy and Chemotherapy on Tregs}

Radiotherapy (RT) adversely affects the immune system, causing severe immune suppression due to non-specific targeting of lymphocytes and haematopoietic progenitor cells. Recent evidence indicates a more complex immune modulating effect of RT, and a potential role for Tregs in determining RT efficacy $[157,158]$.

Tregs are thought to be relatively "radio-resistant", exhibiting reduced apoptotic potential and increased in vivo proliferation compared to other lymphocyte subsets in response to ionizing radiation [159]. In clinical studies of HNSCC, cervical cancer and glioblastoma multiforme, combination chemo-radiotherapy (CRT) depleted $\mathrm{CD} 4^{+}$and $\mathrm{CD} 8^{+}$Teff in the peripheral blood and TDLN of patients, while highly suppressive FoxP3 ${ }^{+}$Tregs were unaffected or expanded [160-162]. The exact mechanisms of RT-resistance in Tregs have not yet been confirmed in humans, although it may rely on upregulation of Akt signaling and the pro-survival proteins Bcl-2/Bcl-x. T cell activation status also confers radio-resistance. Within the TME, highly suppressive and activated Tregs may exhibit stronger RT-resistance compared to "exhausted" CTLs and naïve T cells. RT also induces the generation of tolerogenic DCs following immunogenic cancer cell death [163].

Given this phenomenon of RT-induced Treg expansion or survival, a number of recent trials are testing RT in combination with ICI or neoadjuvant chemotherapy to deplete Tregs [27,164-166]. Results from a pilot study of RT and ipilimumab induced a partial response in only $18 \%$ of metastatic melanoma patients [166]. Targeted radio-immunotherapies utilizing radio-labelled anti-CD25 also showed promising results in a clinical trial of non-Hodgkin's lymphoma [167].

Dosage and timing of RT are critical considerations; low-dose RT may induce anti-inflammatory effects, while higher RT doses deplete Teff and CTLs promoting immune suppression $[158,160]$. Further 
insights into the radiobiology of human Tregs and other immune cell subsets will help to improve RT design, taking into account the role of the immune system in clinical outcomes.

\section{Challenges of Targeting Tregs in Humans}

Learning from current efforts to deplete or impair functions of Tregs, there are a number of challenges to consider when designing Treg-targeted therapies in the context of cancer, and more broadly. These are:

\subsection{Misclassification of Tregs}

Accurate and specific Treg markers are essential for two reasons. First, they enable selective targeting of Tregs in vivo without affecting tumor-specific CTLs and Teff. Second, they allow isolation and monitoring of Tregs during treatment for further investigations.

Most clinical trials currently utilize the canonical Treg markers-FoxP3 and CD25-to identify suppressive Tregs. As discussed earlier, FoxP3 and CD25 are also upregulated on activated non-suppressive T cell subsets. A recent consensus meeting proposed an "essential marker set" for suppressive Tregs; $\mathrm{CD}^{+} / 4^{+} / 25^{+} / 127^{-}$and $\mathrm{FoxP}^{+}$[102]. Robust Treg marker sets or functional assays must be used to confirm the suppressive lineage of proposed Tregs populations.

\subsection{Systemic versus Specific Subset Depletion}

Understanding the most relevant Treg mechanisms or markers within the TME is important for "rationally designing" Treg-targeted immunotherapies. Systemic depletion of FoxP3 ${ }^{+}$Tregs may result in serious immune-related adverse events. It is imperative to target the most suppressive Treg subsets such as Helios-expressing Tregs [104] and CD45RA ${ }^{-}$FoxP3 ${ }^{\text {hi }}$ CD25 ${ }^{\text {hi }}$ eTregs $[8,64]$. In solid tumors, TI Tregs-as suppressive cells on the "front-line" - are the most important Tregs to deplete. Different cancers may have different immune profiles according to location and stage, which can recruit and expand different Treg subsets. For example, mAbs targeting CCR4, a chemokine receptor heavily involved in Treg recruitment to the TME, have shown promising results in clinical and laboratory studies, effectively depleting activated FoxP3 ${ }^{+} \mathrm{CCR} 4^{+}$Tregs with only a limited impact on tumor-infiltrating Teff and CTL subsets [41,45,67-70].

\subsection{Tregs in the Immune Context}

Neoadjuvant therapies aimed at tipping the balance of immune suppression and immune stimulation in favor of an anti-tumor immune response have shown efficacy in a number of clinical studies [168,169]. Considering clinical outcomes, the key determining factor of clinical benefit in ICI and other therapeutic approaches seems to be the CTL: Treg ratio. CD8 ${ }^{+} \mathrm{T}$-cell expansion is associated with better survival in cancer patients treated with anti-CTLA-4 or anti-PD-1 [170-172]. For therapeutic success, it is critical that not only Tregs are depleted, but CTLs are released from T cell exhaustion. This might require use of adjuvant therapies to "reinvigorate CTLs".

\section{Conclusions}

Recent years have highlighted tumor heterogeneity as a critical contributing factor to variable clinical outcomes. Similarly, the immune landscape varies significantly between cancers and patients, influencing the role of Treg subsets in cancer; whether as part of an immunosuppressive network promoting tumor immunity or a protective mechanism controlling cancer-associated inflammation. Tumor-infiltrating Tregs are "front-line" players in the immune response and cancer. From a biological standpoint, understanding the role and contribution of diverse Treg subsets in the tumor microenvironment is a critical first step to designing better therapies. Clinically, the advent of immune checkpoint inhibition, in addition to currently available therapies, offer useful treatment paradigms for Treg depletion or impairment. Targeting tumor-infiltrating Tregs-likely as part of 
a multi-modal treatment strategy_offers an exciting treatment paradigm to re-establish anti-tumor immunity and break immunosuppressive networks within the tumor microenvironment. As discussed here, translating our current knowledge of Treg immunobiology into viable immunotherapies requires a deeper understanding of the immune dynamics of Tregs in various malignancies, the interactions of Tregs with tumor-infiltrating cell subsets, and the impact of different therapeutic modalities on Tregs in vivo.

Acknowledgments: The authors would like to acknowledge the support of The University of Cambridge, Cancer Research UK, Hutchison Whampoa Limited, United Arab Emirates University and Qatar Foundation.

Conflicts of Interest: The authors declare no conflict of interest.

\section{Abbreviations}

The following abbreviations are used in this manuscript:

\begin{tabular}{|c|c|}
\hline $\mathrm{Ab}$ & antibody \\
\hline ADCC & antibody-dependent cell-mediated cytotoxicity \\
\hline $\mathrm{ADCP}$ & antibody-dependent cellular phagocytosis \\
\hline $\mathrm{Ag}$ & antigen \\
\hline $\mathrm{APC}$ & antigen presenting cell \\
\hline CCR & $\mathrm{C}-\mathrm{C}$ motif chemokine receptor \\
\hline CD25 & IL-2 receptor alpha chain \\
\hline COX-2 & cyclooxygenase-2 \\
\hline CRC & colorectal cancer \\
\hline CRT & chemo-radiotherapy \\
\hline CTL & CD8+ cytotoxic t cell \\
\hline CTLA-4 & cytotoxic T-lymphocyte-associated protein 4 \\
\hline CTX & cyclophosphamide \\
\hline CXCR & CXC chemokine receptor \\
\hline eTreg & effector Treg \\
\hline Fc $\gamma$ RIII & Fc gamma receptor III \\
\hline FoxP3 & forkhead box P3 \\
\hline GARP & glycoprotein A repetitions predominant \\
\hline GITR & glucocorticoid-induced TNFR-related protein \\
\hline HAVCR2 & Hepatitis A virus cellular receptor 2 \\
\hline $\mathrm{HBV} / \mathrm{HCV}$ & hepatitis B/C virus \\
\hline $\mathrm{HCC}$ & hepatocellular carcinoma \\
\hline HNC & head and neck cancer \\
\hline HNSCC & head and neck squamous cell carcinoma \\
\hline HPV & human papilloma virus \\
\hline ICI & immune checkpoint inhibition \\
\hline ICOS & Inducible T-cell costimulator \\
\hline IDO & indoleamine 2,3-dioxygenase \\
\hline IFN- $\gamma$ & interferon gamma \\
\hline IL-10/35 & Interleukin 10/35 \\
\hline LAG-3 & lymphocyte activation gene-3 \\
\hline LAP & latency-associated peptide \\
\hline $\mathrm{mAb}$ & monoclonal antibody \\
\hline MDSC & myeloid-derived suppressor cell \\
\hline NK cell & natural killer cell \\
\hline NRP1 & neuropilin 1 \\
\hline PD-1 & programmed death 1 \\
\hline PD-L1 & programmed death-ligand 1 \\
\hline PGE-2 & prostaglandin E-2 \\
\hline pTreg & peripheral Treg \\
\hline RANK & receptor activator of nuclear factor kappa-B \\
\hline RANKL & receptor activator of nuclear factor kappa-B ligand \\
\hline RCC & renal cell carcinoma \\
\hline RT & radiotherapy \\
\hline S1P & sphingosine-1-phosphate \\
\hline
\end{tabular}




$\begin{array}{ll}\text { S1PR1 } & \text { sphingosine-1-phosphate receptor 1 } \\ \text { TAA } & \text { tumor-associated antigen } \\ \text { Tconv } & \text { conventional T cell } \\ \text { TDLN } & \text { tumor-draining lymph node } \\ \text { Teff } & \text { CD4+ T effector cell } \\ \text { TEX } & \text { tumor-derived exosome } \\ \text { TGF- } \beta & \text { Transforming growth factor beta } \\ \text { Th cell } & \text { T helper cell } \\ \text { TI } & \text { tumor-infiltrating } \\ \text { TIGIT } & \text { T cell immunoreceptor with Ig and ITIM domains } \\ \text { TILs } & \text { tumor-infiltrating lymphocytes } \\ \text { TIM-3 } & \text { T-cell immunoglobulin and mucin-domain containing-3 } \\ \text { TME } & \text { tumor microenvironment } \\ \text { Treg } & \text { regulatory T cell } \\ \text { tTreg } & \text { thymic-derived Treg } \\ \text { VEGF-A } & \text { vascular endothelial growth factor-A } \\ \gamma \delta \text { T cell } & \text { gamma delta T cell }\end{array}$

\section{References}

1. Sakaguchi, S.; Yamaguchi, T.; Nomura, T.; Ono, M. Regulatory T cells and immune tolerance. Cell 2008, 133, 775-787. [CrossRef] [PubMed]

2. Lee, H.M.; Bautista, J.L.; Hsieh, C.S. Thymic and peripheral differentiation of regulatory T cells. Adv. Immunol. 2011, 112, 25-71. [PubMed]

3. Yadav, M.; Stephan, S.; Bluestone, J.A. Peripherally induced tregs-Role in immune homeostasis and autoimmunity. Front. Immunol. 2013. [CrossRef] [PubMed]

4. Sakaguchi, S.; Ono, M.; Setoguchi, R.; Yagi, H.; Hori, S.; Fehervari, Z.; Shimizu, J.; Takahashi, T.; Nomura, T. Foxp $3^{+} \mathrm{CD} 25^{+} \mathrm{CD} 4^{+}$natural regulatory $\mathrm{T}$ cells in dominant self-tolerance and autoimmune disease. Immunol. Rev. 2006, 212, 8-27. [CrossRef] [PubMed]

5. Weiner, H.L.; da Cunha, A.P.; Quintana, F.; Wu, H. Oral tolerance. Immunol. Rev. 2011, 241, $241-259$. [CrossRef] [PubMed]

6. Shevach, E.M. Mechanisms of foxp3 $3^{+}$T regulatory cell-mediated suppression. Immunity 2009, 30, 636-645. [CrossRef] [PubMed]

7. Schmidt, A.; Oberle, N.; Krammer, P.H. Molecular mechanisms of treg-mediated T cell suppression. Front. Immunol. 2012. [CrossRef] [PubMed]

8. Miyara, M.; Yoshioka, Y.; Kitoh, A.; Shima, T.; Wing, K.; Niwa, A.; Parizot, C.; Taflin, C.; Heike, T.; Valeyre, D.; et al. Functional delineation and differentiation dynamics of human $\mathrm{CD}^{+}{ }^{+} \mathrm{T}$ cells expressing the FoxP3 transcription factor. Immunity 2009, 30, 899-911. [CrossRef] [PubMed]

9. Duhen, T.; Duhen, R.; Lanzavecchia, A.; Sallusto, F.; Campbell, D.J. Functionally distinct subsets of human FOXP3 $^{+}$Treg cells that phenotypically mirror effector Th cells. Blood 2012, 119, 4430-4440. [CrossRef] [PubMed]

10. Dong, S.; Maiella, S.; Xhaard, A.; Pang, Y.; Wenandy, L.; Larghero, J.; Becavin, C.; Benecke, A.; Bianchi, E.; Socie, G.; et al. Multiparameter single-cell profiling of human $\mathrm{CD}^{+} \mathrm{FOXP}^{+}$regulatory T-cell populations in homeostatic conditions and during graft-versus-host disease. Blood 2013, 122, 1802-1812. [CrossRef] [PubMed]

11. Mason, G.M.; Lowe, K.; Melchiotti, R.; Ellis, R.; de Rinaldis, E.; Peakman, M.; Heck, S.; Lombardi, G.; Tree, T.I. Phenotypic Complexity of the Human Regulatory T Cell Compartment Revealed by Mass Cytometry. J. Immunol. 2015, 195, 2030-2037. [CrossRef] [PubMed]

12. Yamaguchi, T.; Wing, J.B.; Sakaguchi, S. Two modes of immune suppression by Foxp3(+) regulatory T cells under inflammatory or non-inflammatory conditions. Semin. Immunol. 2011, 23, 424-430. [CrossRef] [PubMed]

13. Vignali, D.A. Mechanisms of T(reg) Suppression: Still a Long Way to Go. Front. Immunol. 2012. [CrossRef] [PubMed]

14. Elkord, E.; Alcantar-Orozco, E.M.; Dovedi, S.J.; Tran, D.Q.; Hawkins, R.E.; Gilham, D.E. T regulatory cells in cancer: Recent advances and therapeutic potential. Expert Opin. Biol. Ther. 2010, 10, 1573-1586. [CrossRef] [PubMed] 
15. Nishikawa, H.; Sakaguchi, S. Regulatory T cells in cancer immunotherapy. Curr. Opin. Immunol. 2014, $27,1-7$. [CrossRef] [PubMed]

16. Chaudhary, B.; Abd Al Samid, M.; al-Ramadi, B.K.; Elkord, E. Phenotypic alterations, clinical impact and therapeutic potential of regulatory T cells in cancer. Expert Opin. Biol. Ther. 2014, 14, 931-945. [CrossRef] [PubMed]

17. Curiel, T.J.; Coukos, G.; Zou, L.; Alvarez, X.; Cheng, P.; Mottram, P.; Evdemon-Hogan, M.; Conejo-Garcia, J.R.; Zhang, L.; Burow, M.; et al. Specific recruitment of regulatory T cells in ovarian carcinoma fosters immune privilege and predicts reduced survival. Nat. Med. 2004, 10, 942-949. [CrossRef] [PubMed]

18. Leffers, N.; Gooden, M.J.; de Jong, R.A.; Hoogeboom, B.N.; ten Hoor, K.A.; Hollema, H.; Boezen, H.M.; van der Zee, A.G.; Daemen, T.; Nijman, H.W. Prognostic significance of tumor-infiltrating T-lymphocytes in primary and metastatic lesions of advanced stage ovarian cancer. Cancer Immunol. Immunother. 2009, 58, 449-459. [CrossRef] [PubMed]

19. Jiang, Y.; Du, Z.; Yang, F.; Di, Y.; Li, J.; Zhou, Z.; Pillarisetty, V.G.; Fu, D. FOXP3 ${ }^{+}$lymphocyte density in pancreatic cancer correlates with lymph node metastasis. PLoS ONE 2014, 9, e106741. [CrossRef] [PubMed]

20. Tang, Y.; Xu, X.; Guo, S.; Zhang, C.; Tang, Y.; Tian, Y.; Ni, B.; Lu, B.; Wang, H. An increased abundance of tumor-infiltrating regulatory $\mathrm{T}$ cells is correlated with the progression and prognosis of pancreatic ductal adenocarcinoma. PLoS ONE 2014, 9, e91551. [CrossRef] [PubMed]

21. Tao, H.; Mimura, Y.; Aoe, K.; Kobayashi, S.; Yamamoto, H.; Matsuda, E.; Okabe, K.; Matsumoto, T.; Sugi, K.; Ueoka, H. Prognostic potential of FOXP3 expression in non-small cell lung cancer cells combined with tumor-infiltrating regulatory T cells. Lung Cancer 2012, 75, 95-101. [CrossRef] [PubMed]

22. Sayour, E.J.; McLendon, P.; McLendon, R.; De Leon, G.; Reynolds, R.; Kresak, J.; Sampson, J.H.; Mitchell, D.A. Increased proportion of FoxP3 ${ }^{+}$regulatory $\mathrm{T}$ cells in tumor infiltrating lymphocytes is associated with tumor recurrence and reduced survival in patients with glioblastoma. Cancer Immunol. Immunother. 2015, 64, 419-427. [CrossRef] [PubMed]

23. Yang, Z.Z.; Novak, A.J.; Stenson, M.J.; Witzig, T.E.; Ansell, S.M. Intratumoral CD4 ${ }^{+}$CD25 ${ }^{+}$regulatory T-cell-mediated suppression of infiltrating $\mathrm{CD}^{+} \mathrm{T}$ cells in B-cell non-Hodgkin lymphoma. Blood 2006, 107, 3639-3646. [CrossRef] [PubMed]

24. DeLeeuw, R.J.; Kost, S.E.; Kakal, J.A.; Nelson, B.H. The prognostic value of FoxP3 ${ }^{+}$tumor-infiltrating lymphocytes in cancer: A critical review of the literature. Clin. Cancer Res. 2012, 18, 3022-3029. [CrossRef] [PubMed]

25. Shang, B.; Liu, Y.; Jiang, S.J.; Liu, Y. Prognostic value of tumor-infiltrating FoxP3 ${ }^{+}$regulatory T cells in cancers: A systematic review and meta-analysis. Sci. Rep. 2015. [CrossRef] [PubMed]

26. Rasku, M.A.; Clem, A.L.; Telang, S.; Taft, B.; Gettings, K.; Gragg, H.; Cramer, D.; Lear, S.C.; McMasters, K.M.; Miller, D.M.; et al. Transient T cell depletion causes regression of melanoma metastases. J. Transl. Med. 2008. [CrossRef] [PubMed]

27. Ladoire, S.; Arnould, L.; Apetoh, L.; Coudert, B.; Martin, F.; Chauffert, B.; Fumoleau, P.; Ghiringhelli, F. Pathologic complete response to neoadjuvant chemotherapy of breast carcinoma is associated with the disappearance of tumor-infiltrating foxp3+ regulatory T cells. Clin. Cancer Res. 2008, 14, 2413-2420. [CrossRef] [PubMed]

28. Rech, A.J.; Mick, R.; Martin, S.; Recio, A.; Aqui, N.A.; Powell, D.J., Jr.; Colligon, T.A.; Trosko, J.A.; Leinbach, L.I.; Pletcher, C.H.; et al. CD25 blockade depletes and selectively reprograms regulatory T cells in concert with immunotherapy in cancer patients. Sci. Transl. Med. 2012. [CrossRef] [PubMed]

29. Haas, M.; Dimmler, A.; Hohenberger, W.; Grabenbauer, G.G.; Niedobitek, G.; Distel, L.V. Stromal regulatory T-cells are associated with a favourable prognosis in gastric cancer of the cardia. BMC Gastroenterol. 2009. [CrossRef] [PubMed]

30. Salama, P.; Phillips, M.; Grieu, F.; Morris, M.; Zeps, N.; Joseph, D.; Platell, C.; Iacopetta, B. Tumor-infiltrating $\mathrm{FOXP}^{+} \mathrm{T}$ regulatory cells show strong prognostic significance in colorectal cancer. J. Clin. Oncol. 2009, 27, 186-192. [CrossRef] [PubMed]

31. Ladoire, S.; Martin, F.; Ghiringhelli, F. Prognostic role of FOXP3 ${ }^{+}$regulatory T cells infiltrating human carcinomas: The paradox of colorectal cancer. Cancer Immunol. Immunother. 2011, 60, 909-918. [CrossRef] [PubMed]

32. Ondondo, B.; Jones, E.; Godkin, A.; Gallimore, A. Home sweet home: The tumor microenvironment as a haven for regulatory T cells. Front. Immunol. 2013. [CrossRef] [PubMed] 
33. Kim, C.H. Reining in FoxP3(+) regulatory T cells by the sphingosine 1-phosphate-S1P1 axis. Immunol. Cell Biol. 2009, 87, 502-504. [CrossRef] [PubMed]

34. Priceman, S.J.; Shen, S.; Wang, L.; Deng, J.; Yue, C.; Kujawski, M.; Yu, H. S1PR1 is crucial for accumulation of regulatory T cells in tumors via STAT3. Cell Rep. 2014, 6, 992-999. [CrossRef] [PubMed]

35. Fridman, W.H.; Pages, F.; Sautes-Fridman, C.; Galon, J. The immune contexture in human tumours: Impact on clinical outcome. Nat. Rev. Cancer 2012, 12, 298-306. [CrossRef] [PubMed]

36. Giraldo, N.A.; Becht, E.; Remark, R.; Damotte, D.; Sautes-Fridman, C.; Fridman, W.H. The immune contexture of primary and metastatic human tumours. Curr. Opin. Immunol. 2014, 27, 8-15. [CrossRef] [PubMed]

37. Kakita, N.; Kanto, T.; Itose, I.; Kuroda, S.; Inoue, M.; Matsubara, T.; Higashitani, K.; Miyazaki, M.; Sakakibara, M.; Hiramatsu, N.; et al. Comparative analyses of regulatory T cell subsets in patients with hepatocellular carcinoma: A crucial role of CD25(-)FOXP3(-) T cells. Int. J. Cancer 2012, 131, 2573-2583. [CrossRef] [PubMed]

38. Schuler, P.J.; Schilling, B.; Harasymczuk, M.; Hoffmann, T.K.; Johnson, J.; Lang, S.; Whiteside, T.L. Phenotypic and functional characteristics of $\mathrm{CD}^{+}{ }^{+} \mathrm{CD} 39^{+} \mathrm{FOXP} 3^{+}$and $\mathrm{CD} 4{ }^{+} \mathrm{CD} 39^{+} \mathrm{FOXP} 3$ neg T-cell subsets in cancer patients. Eur. J. Immunol. 2012, 42, 1876-1885. [CrossRef] [PubMed]

39. Jie, H.B.; Gildener-Leapman, N.; Li, J.; Srivastava, R.M.; Gibson, S.P.; Whiteside, T.L.; Ferris, R.L. Intratumoral regulatory $\mathrm{T}$ cells upregulate immunosuppressive molecules in head and neck cancer patients. Br. J. Cancer 2013, 109, 2629-2635. [CrossRef] [PubMed]

40. Lin, Y.C.; Mahalingam, J.; Chiang, J.M.; Su, P.J.; Chu, Y.Y.; Lai, H.Y.; Fang, J.H.; Huang, C.T.; Chiu, C.T.; Lin, C.Y. Activated but not resting regulatory $\mathrm{T}$ cells accumulated in tumor microenvironment and correlated with tumor progression in patients with colorectal cancer. Int. J. Cancer 2013, 132, 1341-1350. [CrossRef] [PubMed]

41. Sugiyama, D.; Nishikawa, H.; Maeda, Y.; Nishioka, M.; Tanemura, A.; Katayama, I.; Ezoe, S.; Kanakura, Y.; Sato, E.; Fukumori, Y.; et al. Anti-CCR4 mAb selectively depletes effector-type FoxP3 ${ }^{+} \mathrm{CD}^{+}{ }^{+}$regulatory T cells, evoking antitumor immune responses in humans. Proc. Natl. Acad. Sci. USA 2013, 110, 17945-17950. [CrossRef] [PubMed]

42. Pedroza-Gonzalez, A.; Verhoef, C.; Ijzermans, J.N.; Peppelenbosch, M.P.; Kwekkeboom, J.; Verheij, J.; Janssen, H.L.; Sprengers, D. Activated tumor-infiltrating $\mathrm{CD}^{+}{ }^{+}$regulatory T cells restrain antitumor immunity in patients with primary or metastatic liver cancer. Hepatology 2013, 57, 183-194. [CrossRef] [PubMed]

43. Han, Y.; Yang, Y.; Chen, Z.; Jiang, Z.; Gu, Y.; Liu, Y.; Xu, S.; Lin, C.; Pan, Z.; Zhou, W.; et al. Human hepatocellular carcinoma-infiltrating CD4(+)CD69(+)Foxp3(-) regulatory $\mathrm{T}$ cell suppresses $\mathrm{T}$ cell response via membrane-bound TGF-beta1. J. Mol. Med. (Berl.) 2014, 92, 539-550. [CrossRef] [PubMed]

44. Scurr, M.; Ladell, K.; Besneux, M.; Christian, A.; Hockey, T.; Smart, K.; Bridgeman, H.; Hargest, R.; Phillips, S.; Davies, M.; et al. Highly prevalent colorectal cancer-infiltrating LAP(+) Foxp3(-) T cells exhibit more potent immunosuppressive activity than Foxp3(+) regulatory T cells. Mucosal Immunol. 2014, 7, 428-439. [CrossRef] [PubMed]

45. Kurose, K.; Ohue, Y.; Sato, E.; Yamauchi, A.; Eikawa, S.; Isobe, M.; Nishio, Y.; Uenaka, A.; Oka, M.; Nakayama, E. Increase in activated Treg in TIL in lung cancer and in vitro depletion of Treg by ADCC using an antihuman CCR4 mAb (KM2760). J. Thorac. Oncol. 2015, 10, 74-83. [CrossRef] [PubMed]

46. Amedei, A.; Niccolai, E.; Benagiano, M.; Della Bella, C.; Cianchi, F.; Bechi, P.; Taddei, A.; Bencini, L.; Farsi, M.; Cappello, P.; et al. Ex vivo analysis of pancreatic cancer-infiltrating T lymphocytes reveals that ENO-specific Tregs accumulate in tumor tissue and inhibit Th1/Th17 effector cell functions. Cancer Immunol. Immunother. 2013, 62, 1249-1260. [CrossRef] [PubMed]

47. Yi, Y.; He, H.W.; Wang, J.X.; Cai, X.Y.; Li, Y.W.; Zhou, J.; Cheng, Y.F.; Jin, J.J.; Fan, J.; Qiu, S.J. The functional impairment of HCC-infiltrating gammadelta $\mathrm{T}$ cells, partially mediated by regulatory $\mathrm{T}$ cells in a TGFbetaand IL-10-dependent manner. J. Hepatol. 2013, 58, 977-983. [CrossRef] [PubMed]

48. Yuan, X.L.; Chen, L.; Li, M.X.; Dong, P.; Xue, J.; Wang, J.; Zhang, T.T.; Wang, X.A.; Zhang, F.M.; Ge, H.L.; et al. Elevated expression of Foxp3 in tumor-infiltrating Treg cells suppresses T-cell proliferation and contributes to gastric cancer progression in a COX-2-dependent manner. Clin. Immunol. 2010, 134, 277-288. [CrossRef] [PubMed]

49. Yan, J.; Zhang, Y.; Zhang, J.P.; Liang, J.; Li, L.; Zheng, L. Tim-3 expression defines regulatory T cells in human tumors. PLoS ONE 2013, 8, e58006. [CrossRef] [PubMed] 
50. Bu, M.; Shen, Y.; Seeger, W.L.; An, S.; Qi, R.; Sanderson, J.A.; Cai, Y. Ovarian carcinoma-infiltrating regulatory $\mathrm{T}$ cells were more potent suppressors of CD8(+) T cell inflammation than their peripheral counterparts, a function dependent on TIM3 expression. Tumour Biol. 2016, 37, 3949-3956. [CrossRef] [PubMed]

51. Nirschl, C.J.; Drake, C.G. Molecular pathways: Coexpression of immune checkpoint molecules: Signaling pathways and implications for cancer immunotherapy. Clin. Cancer Res. 2013, 19, 4917-4924. [CrossRef] [PubMed]

52. Buchbinder, E.I.; Desai, A. CTLA-4 and PD-1 Pathways: Similarities, Differences, and Implications of Their Inhibition. Am. J. Clin. Oncol. 2016, 39, 98-106. [CrossRef] [PubMed]

53. Rifkin, D.B. Latent transforming growth factor-beta (TGF-beta) binding proteins: Orchestrators of TGF-beta availability. J. Biol. Chem. 2005, 280, 7409-7412. [CrossRef] [PubMed]

54. Tran, D.Q.; Andersson, J.; Wang, R.; Ramsey, H.; Unutmaz, D.; Shevach, E.M. GARP (LRRC32) is essential for the surface expression of latent TGF-beta on platelets and activated FOXP3+ regulatory $\mathrm{T}$ cells. Proc. Natl. Acad. Sci. USA 2009, 106, 13445-13450. [CrossRef] [PubMed]

55. Sun, J.; Tang, D.N.; Fu, T.; Sharma, P. Identification of human regulatory T cells in the setting of T-cell activation and anti-CTLA-4 immunotherapy on the basis of expression of latency-associated peptide. Cancer Discov. 2012, 2, 122-130. [CrossRef] [PubMed]

56. Mahalingam, J.; Lin, C.Y.; Chiang, J.M.; Su, P.J.; Chu, Y.Y.; Lai, H.Y.; Fang, J.H.; Huang, C.T.; Lin, Y.C. CD4(+) T cells expressing latency-associated peptide and Foxp3 are an activated subgroup of regulatory T cells enriched in patients with colorectal cancer. PLoS ONE 2014, 9, e108554. [CrossRef] [PubMed]

57. Abd Al Samid, M.; Chaudhary, B.; Khaled, Y.S.; Ammori, B.J.; Elkord, E. Combining FoxP3 and Helios with GARP/LAP markers can identify expanded Treg subsets in cancer patients. Oncotarget 2016, 7, 14083-14094. [PubMed]

58. Whiteside, T.L. What are regulatory T cells (Treg) regulating in cancer and why? Semin. Cancer Biol. 2012, 22, 327-334. [CrossRef] [PubMed]

59. Sundstrom, P.; Stenstad, H.; Langenes, V.; Ahlmanner, F.; Theander, L.; Ndah, T.G.; Fredin, K.; Borjesson, L.; Gustavsson, B.; Bastid, J.; et al. Regulatory T Cells from Colon Cancer Patients Inhibit Effector T-cell Migration through an Adenosine-Dependent Mechanism. Cancer Immunol. Res. 2016, 4, 183-193. [CrossRef] [PubMed]

60. Schuler, P.J.; Saze, Z.; Hong, C.S.; Muller, L.; Gillespie, D.G.; Cheng, D.; Harasymczuk, M.; Mandapathil, M.; Lang, S.; Jackson, E.K.; et al. Human CD4+ CD39+ regulatory T cells produce adenosine upon co-expression of surface CD73 or contact with CD73+ exosomes or CD73+ cells. Clin. Exp. Immunol. 2014, 177, 531-543. [CrossRef] [PubMed]

61. Dunne, M.R.; Ryan, C.; Nolan, B.; Tosetto, M.; Geraghty, R.; Winter, D.C.; O'Connell, P.R.; Hyland, J.M.; Doherty, G.A.; Sheahan, K.; et al. Enrichment of Inflammatory IL-17 and TNF-alpha Secreting CD4(+) T Cells within Colorectal Tumors despite the Presence of Elevated CD39(+) T Regulatory Cells and Increased Expression of the Immune Checkpoint Molecule, PD-1. Front. Oncol. 2016. [CrossRef] [PubMed]

62. Deaglio, S.; Dwyer, K.M.; Gao, W.; Friedman, D.; Usheva, A.; Erat, A.; Chen, J.F.; Enjyoji, K.; Linden, J.; Oukka, M.; et al. Adenosine generation catalyzed by CD39 and CD73 expressed on regulatory T cells mediates immune suppression. J. Exp. Med. 2007, 204, 1257-1265. [CrossRef] [PubMed]

63. Strauss, L.; Bergmann, C.; Szczepanski, M.; Gooding, W.; Johnson, J.T.; Whiteside, T.L. A unique subset of CD4+CD25highFoxp3+ T cells secreting interleukin-10 and transforming growth factor-beta1 mediates suppression in the tumor microenvironment. Clin. Cancer Res. 2007, 13, 4345-4354. [CrossRef] [PubMed]

64. Saito, T.; Nishikawa, H.; Wada, H.; Nagano, Y.; Sugiyama, D.; Atarashi, K.; Maeda, Y.; Hamaguchi, M.; Ohkura, N.; Sato, E.; et al. Two FOXP3CD4 T cell subpopulations distinctly control the prognosis of colorectal cancers. Nat. Med. 2016, 22, 679-684. [CrossRef] [PubMed]

65. Mailloux, A.W.; Young, M.R. Regulatory T-cell trafficking: From thymic development to tumor-induced immune suppression. Crit. Rev. Immunol. 2010, 30, 435-447. [CrossRef] [PubMed]

66. Kavanagh, B.; O’Brien, S.; Lee, D.; Hou, Y.; Weinberg, V.; Rini, B.; Allison, J.P.; Small, E.J.; Fong, L. CTLA4 blockade expands FoxP3+ regulatory and activated effector CD4+ T cells in a dose-dependent fashion. Blood 2008, 112, 1175-1183. [CrossRef] [PubMed]

67. Ishida, T.; Joh, T.; Uike, N.; Yamamoto, K.; Utsunomiya, A.; Yoshida, S.; Saburi, Y.; Miyamoto, T.; Takemoto, S.; Suzushima, H.; et al. Defucosylated anti-CCR4 monoclonal antibody (KW-0761) for relapsed adult T-cell leukemia-lymphoma: A multicenter phase II study. J. Clin. Oncol. 2012, 30, 837-842. [CrossRef] [PubMed] 
68. Ogura, M.; Ishida, T.; Hatake, K.; Taniwaki, M.; Ando, K.; Tobinai, K.; Fujimoto, K.; Yamamoto, K.; Miyamoto, T.; Uike, N.; et al. Multicenter phase II study of mogamulizumab (KW-0761), a defucosylated anti-cc chemokine receptor 4 antibody, in patients with relapsed peripheral T-cell lymphoma and cutaneous T-cell lymphoma. J. Clin. Oncol. 2014, 32, 1157-1163. [CrossRef] [PubMed]

69. Kurose, K.; Ohue, Y.; Wada, H.; Iida, S.; Ishida, T.; Kojima, T.; Doi, T.; Suzuki, S.; Isobe, M.; Funakoshi, T.; et al. Phase Ia Study of FoxP3+ CD4 Treg Depletion by Infusion of a Humanized Anti-CCR4 Antibody, KW-0761, in Cancer Patients. Clin. Cancer Res. 2015, 21, 4327-4336. [CrossRef] [PubMed]

70. Ni, X.; Jorgensen, J.L.; Goswami, M.; Challagundla, P.; Decker, W.K.; Kim, Y.H.; Duvic, M.A. Reduction of regulatory T cells by Mogamulizumab, a defucosylated anti-CC chemokine receptor 4 antibody, in patients with aggressive/refractory mycosis fungoides and Sezary syndrome. Clin. Cancer Res. 2015, 21, 274-285. [CrossRef] [PubMed]

71. Whiteside, T.L. The tumor microenvironment and its role in promoting tumor growth. Oncogene 2008, 27, 5904-5912. [CrossRef] [PubMed]

72. Jiang, Y.; Li, Y.; Zhu, B. T-cell exhaustion in the tumor microenvironment. Cell. Death Dis. 2015, 6, e1792. [CrossRef] [PubMed]

73. Lindau, D.; Gielen, P.; Kroesen, M.; Wesseling, P.; Adema, G.J. The immunosuppressive tumour network: Myeloid-derived suppressor cells, regulatory T cells and natural killer T cells. Immunology 2013, 138, 105-115. [CrossRef] [PubMed]

74. Pedroza-Pacheco, I.; Madrigal, A.; Saudemont, A. Interaction between natural killer cells and regulatory T cells: Perspectives for immunotherapy. Cell. Mol. Immunol. 2013, 10, 222-229. [CrossRef] [PubMed]

75. Ghiringhelli, F.; Menard, C.; Terme, M.; Flament, C.; Taieb, J.; Chaput, N.; Puig, P.E.; Novault, S.; Escudier, B.; Vivier, E.; et al. CD4+CD25+ regulatory T cells inhibit natural killer cell functions in a transforming growth factor-beta-dependent manner. J. Exp. Med. 2005, 202, 1075-1085. [CrossRef] [PubMed]

76. Chang, W.C.; Li, C.H.; Chu, L.H.; Huang, P.S.; Sheu, B.C.; Huang, S.C. Regulatory T Cells Suppress Natural Killer Cell Immunity in Patients With Human Cervical Carcinoma. Int. J. Gynecol. Cancer 2016, 26, 156-162. [CrossRef] [PubMed]

77. Khaled, Y.S.; Ammori, B.J.; Elkord, E. Myeloid-derived suppressor cells in cancer: Recent progress and prospects. Immunol. Cell Biol. 2013, 91, 493-502. [CrossRef] [PubMed]

78. Dannenmann, S.R.; Thielicke, J.; Stockli, M.; Matter, C.; von Boehmer, L.; Cecconi, V.; Hermanns, T.; Hefermehl, L.; Schraml, P.; Moch, H.; et al. Tumor-associated macrophages subvert T-cell function and correlate with reduced survival in clear cell renal cell carcinoma. Oncoimmunology 2013, 2, e23562. [CrossRef] [PubMed]

79. Tiemessen, M.M.; Jagger, A.L.; Evans, H.G.; van Herwijnen, M.J.; John, S.; Taams, L.S. CD4+CD25+Foxp3+ regulatory $\mathrm{T}$ cells induce alternative activation of human monocytes/macrophages. Proc. Natl. Acad. Sci. USA 2007, 104, 19446-19451. [CrossRef] [PubMed]

80. Fujimura, T.; Kambayashi, Y.; Aiba, S. Crosstalk between regulatory T cells (Tregs) and myeloid derived suppressor cells (MDSCs) during melanoma growth. Oncoimmunology 2012, 1, 1433-1434. [CrossRef] [PubMed]

81. Pyzer, A.R.; Cole, L.; Rosenblatt, J.; Avigan, D.E. Myeloid-derived suppressor cells as effectors of immune suppression in cancer. Int. J. Cancer 2016. [CrossRef] [PubMed]

82. Maldonado, R.A.; von Andrian, U.H. How tolerogenic dendritic cells induce regulatory T cells. Adv. Immunol. 2010, 108, 111-165. [PubMed]

83. Pedroza-Gonzalez, A.; Zhou, G.; Vargas-Mendez, E.; Boor, P.P.; Mancham, S.; Verhoef, C.; Polak, W.G.; Grunhagen, D.; Pan, Q.; Janssen, H.; et al. Tumor-infiltrating plasmacytoid dendritic cells promote immunosuppression by Tr1 cells in human liver tumors. Oncoimmunology 2015, 4, e1008355. [PubMed]

84. Burr, S.P.; Dazzi, F.; Garden, O.A. Mesenchymal stromal cells and regulatory T cells: The Yin and Yang of peripheral tolerance? Immunol. Cell Biol. 2013, 91, 12-18. [PubMed]

85. Taflin, C.; Favier, B.; Baudhuin, J.; Savenay, A.; Hemon, P.; Bensussan, A.; Charron, D.; Glotz, D.; Mooney, N. Human endothelial cells generate Th17 and regulatory T cells under inflammatory conditions. Proc. Natl. Acad. Sci. USA 2011, 108, 2891-2896. [CrossRef] [PubMed]

86. Fu, H.; Kishore, M.; Gittens, B.; Wang, G.; Coe, D.; Komarowska, I.; Infante, E.; Ridley, A.J.; Cooper, D.; Perretti, M.; et al. Self-recognition of the endothelium enables regulatory T-cell trafficking and defines the kinetics of immune regulation. Nat. Commun. 2014. [CrossRef] [PubMed] 
87. Brinkman, C.C.; Iwami, D.; Hritzo, M.K.; Xiong, Y.; Ahmad, S.; Simon, T.; Hippen, K.L.; Blazar, B.R.; Bromberg, J.S. Treg engage lymphotoxin beta receptor for afferent lymphatic transendothelial migration. Nat. Commun. 2016. [CrossRef] [PubMed]

88. Maganto-Garcia, E.; Bu, D.X.; Tarrio, M.L.; Alcaide, P.; Newton, G.; Griffin, G.K.; Croce, K.J.; Luscinskas, F.W.; Lichtman, A.H.; Grabie, N. Foxp $3^{+}$-inducible regulatory T cells suppress endothelial activation and leukocyte recruitment. J. Immunol. 2011, 187, 3521-3529. [CrossRef] [PubMed]

89. Giatromanolaki, A.; Bates, G.J.; Koukourakis, M.I.; Sivridis, E.; Gatter, K.C.; Harris, A.L.; Banham, A.H. The presence of tumor-infiltrating FOXP3+ lymphocytes correlates with intratumoral angiogenesis in endometrial cancer. Gynecol. Oncol. 2008, 110, 216-221. [CrossRef] [PubMed]

90. Facciabene, A.; Peng, X.; Hagemann, I.S.; Balint, K.; Barchetti, A.; Wang, L.P.; Gimotty, P.A.; Gilks, C.B.; Lal, P.; Zhang, L.; et al. Tumour hypoxia promotes tolerance and angiogenesis via CCL28 and T(reg) cells. Nature 2011, 475, 226-230. [CrossRef] [PubMed]

91. Muller, L.; Mitsuhashi, M.; Simms, P.; Gooding, W.E.; Whiteside, T.L. Tumor-derived exosomes regulate expression of immune function-related genes in human T cell subsets. Sci. Rep. 2016. [CrossRef] [PubMed]

92. Whiteside, T.L. Induced regulatory $\mathrm{T}$ cells in inhibitory microenvironments created by cancer. Expert Opin. Biol. Ther. 2014, 14, 1411-1425. [CrossRef] [PubMed]

93. Zhou, X.; Tang, J.; Cao, H.; Fan, H.; Li, B. Tissue resident regulatory T cells: Novel therapeutic targets for human disease. Cell. Mol. Immunol. 2015, 12, 543-552. [CrossRef] [PubMed]

94. Trinchieri, G. Cancer and inflammation: An old intuition with rapidly evolving new concepts. Annu. Rev. Immunol. 2012, 30, 677-706. [CrossRef] [PubMed]

95. Bremnes, R.M.; Al-Shibli, K.; Donnem, T.; Sirera, R.; Al-Saad, S.; Andersen, S.; Stenvold, H.; Camps, C.; Busund, L.T. The role of tumor-infiltrating immune cells and chronic inflammation at the tumor site on cancer development, progression, and prognosis: Emphasis on non-small cell lung cancer. J. Thorac. Oncol. 2011, 6, 824-833. [CrossRef] [PubMed]

96. Smigiel, K.S.; Srivastava, S.; Stolley, J.M.; Campbell, D.J. Regulatory T-cell homeostasis: Steady-state maintenance and modulation during inflammation. Immunol. Rev. 2014, 259, 40-59. [CrossRef] [PubMed]

97. Erdman, S.E.; Rao, V.P.; Olipitz, W.; Taylor, C.L.; Jackson, E.A.; Levkovich, T.; Lee, C.W.; Horwitz, B.H.; Fox, J.G.; Ge, Z.; et al. Unifying roles for regulatory T cells and inflammation in cancer. Int. J. Cancer 2010, 126, 1651-1665. [CrossRef] [PubMed]

98. Bergmann, C.; Strauss, L.; Wang, Y.; Szczepanski, M.J.; Lang, S.; Johnson, J.T.; Whiteside, T.L. T regulatory type 1 cells in squamous cell carcinoma of the head and neck: Mechanisms of suppression and expansion in advanced disease. Clin. Cancer Res. 2008, 14, 3706-3715. [CrossRef] [PubMed]

99. Betts, G.; Jones, E.; Junaid, S.; El-Shanawany, T.; Scurr, M.; Mizen, P.; Kumar, M.; Jones, S.; Rees, B.; Williams, G.; et al. Suppression of tumour-specific CD4(+) T cells by regulatory T cells is associated with progression of human colorectal cancer. Gut 2012, 61, 1163-1171. [CrossRef] [PubMed]

100. Gavin, M.A.; Torgerson, T.R.; Houston, E.; DeRoos, P.; Ho, W.Y.; Stray-Pedersen, A.; Ocheltree, E.L.; Greenberg, P.D.; Ochs, H.D.; Rudensky, A.Y. Single-cell analysis of normal and FOXP3-mutant human T cells: FOXP3 expression without regulatory T cell development. Proc. Natl. Acad. Sci. USA 2006, 103, 6659-6664. [CrossRef] [PubMed]

101. Tran, D.Q.; Ramsey, H.; Shevach, E.M. Induction of FOXP3 expression in naive human CD4+FOXP3 T cells by T-cell receptor stimulation is transforming growth factor-beta dependent but does not confer a regulatory phenotype. Blood 2007, 110, 2983-2990. [CrossRef] [PubMed]

102. Santegoets, S.J.; Dijkgraaf, E.M.; Battaglia, A.; Beckhove, P.; Britten, C.M.; Gallimore, A.; Godkin, A.; Gouttefangeas, C.; de Gruijl, T.D.; Koenen, H.J.; et al. Monitoring regulatory T cells in clinical samples: consensus on an essential marker set and gating strategy for regulatory $\mathrm{T}$ cell analysis by flow cytometry. Cancer Immunol. Immunother. 2015, 64, 1271-1286. [CrossRef] [PubMed]

103. Adeegbe, D.O; Nishikawa, H. Natural and induced T regulatory cells in cancer. Front. Immunol. 2013. [CrossRef] [PubMed]

104. Elkord, E.; Abd Al Samid, M.; Chaudhary, B. Helios, and not FoxP3, is the marker of activated Tregs expressing GARP/LAP. Oncotarget 2015, 6, 20026-20036. [CrossRef] [PubMed]

105. Marshall, N.A.; Christie, L.E.; Munro, L.R.; Culligan, D.J.; Johnston, P.W.; Barker, R.N.; Vickers, M.A. Immunosuppressive regulatory $\mathrm{T}$ cells are abundant in the reactive lymphocytes of Hodgkin lymphoma. Blood 2004, 103, 1755-1762. [CrossRef] [PubMed] 
106. Dobrzanski, M.J.; Rewers-Felkins, K.A.; Samad, K.A.; Quinlin, I.S.; Phillips, C.A.; Robinson, W.; Dobrzanski, D.J.; Wright, S.E. Immunotherapy with IL-10- and IFN-gamma-producing CD4 effector cells modulate "Natural" and "Inducible" CD4 TReg cell subpopulation levels: Observations in four cases of patients with ovarian cancer. Cancer Immunol. Immunother. 2012, 61, 839-854. [CrossRef] [PubMed]

107. Wing, J.B.; Sakaguchi, S. Multiple treg suppressive modules and their adaptability. Front. Immunol. 2012. [CrossRef] [PubMed]

108. Redjimi, N.; Raffin, C.; Raimbaud, I.; Pignon, P.; Matsuzaki, J.; Odunsi, K.; Valmori, D.; Ayyoub, M. CXCR3+ T regulatory cells selectively accumulate in human ovarian carcinomas to limit type I immunity. Cancer Res. 2012, 72, 4351-4360. [CrossRef] [PubMed]

109. Savage, P.A.; Leventhal, D.S.; Malchow, S. Shaping the repertoire of tumor-infiltrating effector and regulatory T cells. Immunol. Rev. 2014, 259, 245-258. [CrossRef] [PubMed]

110. Lu, Y.C.; Robbins, P.F. Cancer immunotherapy targeting neoantigens. Semin. Immunol. 2016, $28,22-27$. [CrossRef] [PubMed]

111. Francois, V.; Ottaviani, S.; Renkvist, N.; Stockis, J.; Schuler, G.; Thielemans, K.; Colau, D.; Marchand, M.; Boon, T.; Lucas, S.; et al. The CD4(+) T-cell response of melanoma patients to a MAGE-A3 peptide vaccine involves potential regulatory T cells. Cancer Res. 2009, 69, 4335-4345. [CrossRef] [PubMed]

112. Fourcade, J.; Sun, Z.; Kudela, P.; Janjic, B.; Kirkwood, J.M.; El-Hafnawy, T.; Zarour, H.M. Human tumor antigen-specific helper and regulatory $\mathrm{T}$ cells share common epitope specificity but exhibit distinct $\mathrm{T}$ cell repertoire. J. Immunol. 2010, 184, 6709-6718. [CrossRef] [PubMed]

113. Horn, T.; Grab, J.; Schusdziarra, J.; Schmid, S.; Maurer, T.; Nawroth, R.; Wolf, P.; Pritsch, M.; Gschwend, J.E.; Kubler, H.R.; et al. Antitumor T cell responses in bladder cancer are directed against a limited set of antigens and are modulated by regulatory T cells and routine treatment approaches. Int. J. Cancer 2013, 133, 2145-2156. [CrossRef] [PubMed]

114. Ayyoub, M.; Pignon, P.; Classe, J.M.; Odunsi, K.; Valmori, D. CD4+ T effectors specific for the tumor antigen NY-ESO-1 are highly enriched at ovarian cancer sites and coexist with, but are distinct from, tumor-associated Treg. Cancer Immunol. Res. 2013, 1, 303-308. [CrossRef] [PubMed]

115. Bindea, G.; Mlecnik, B.; Tosolini, M.; Kirilovsky, A.; Waldner, M.; Obenauf, A.C.; Angell, H.; Fredriksen, T.; Lafontaine, L.; Berger, A.; et al. Spatiotemporal dynamics of intratumoral immune cells reveal the immune landscape in human cancer. Immunity 2013, 39, 782-795. [CrossRef] [PubMed]

116. Gobert, M.; Treilleux, I.; Bendriss-Vermare, N.; Bachelot, T.; Goddard-Leon, S.; Arfi, V.; Biota, C.; Doffin, A.C.; Durand, I.; Olive, D.; et al. Regulatory T cells recruited through CCL22/CCR4 are selectively activated in lymphoid infiltrates surrounding primary breast tumors and lead to an adverse clinical outcome. Cancer Res. 2009, 69, 2000-2009. [CrossRef] [PubMed]

117. Faget, J.; Biota, C.; Bachelot, T.; Gobert, M.; Treilleux, I.; Goutagny, N.; Durand, I.; Leon-Goddard, S.; Blay, J.Y.; Caux, C.; et al. Early detection of tumor cells by innate immune cells leads to T(reg) recruitment through CCL22 production by tumor cells. Cancer Res. 2011, 71, 6143-6152. [CrossRef] [PubMed]

118. Darrasse-Jeze, G.; Podsypanina, K. How numbers, nature, and immune status of foxp3(+) regulatory T-cells shape the early immunological events in tumor development. Front. Immunol. 2013. [CrossRef] [PubMed]

119. Halvorsen, E.C.; Mahmoud, S.M.; Bennewith, K.L. Emerging roles of regulatory T cells in tumour progression and metastasis. Cancer Metastasis Rev. 2014, 33, 1025-1041. [CrossRef] [PubMed]

120. Tan, W.; Zhang, W.; Strasner, A.; Grivennikov, S.; Cheng, J.Q.; Hoffman, R.M.; Karin, M. Tumour-infiltrating regulatory $\mathrm{T}$ cells stimulate mammary cancer metastasis through RANKL-RANK signalling. Nature 2011, 470, 548-553. [CrossRef] [PubMed]

121. Ye, Y.; Zhou, Z.; Gu, W.; Peng, F.; Li, J. Treg increases HepG2 cell growth by RANK-RANKL pathway. J. Immunother. Cancer 2014. [CrossRef]

122. Whiteside, T. The role of regulatory T cells in cancer immunology. Immunotargets Ther. 2015, 4, $159-171$. [CrossRef] [PubMed]

123. Gajewski, T.F.; Schreiber, H.; Fu, Y.X. Innate and adaptive immune cells in the tumor microenvironment. Nat. Immunol. 2013, 14, 1014-1022. [CrossRef] [PubMed]

124. Pere, H.; Tanchot, C.; Bayry, J.; Terme, M.; Taieb, J.; Badoual, C.; Adotevi, O.; Merillon, N.; Marcheteau, E.; Quillien, V.R.; et al. Comprehensive analysis of current approaches to inhibit regulatory T cells in cancer. Oncoimmunology 2012, 1, 326-333. [CrossRef] [PubMed] 
125. Ghiringhelli, F.; Larmonier, N.; Schmitt, E.; Parcellier, A.; Cathelin, D.; Garrido, C.; Chauffert, B.; Solary, E.; Bonnotte, B.; Martin, F. CD4+CD25+ regulatory T cells suppress tumor immunity but are sensitive to cyclophosphamide which allows immunotherapy of established tumors to be curative. Eur. J. Immunol. 2004, 34, 336-344. [CrossRef] [PubMed]

126. Lutsiak, M.E.; Semnani, R.T.; De Pascalis, R.; Kashmiri, S.V.; Schlom, J.; Sabzevari, H. Inhibition of CD4(+)25+ T regulatory cell function implicated in enhanced immune response by low-dose cyclophosphamide. Blood 2005, 105, 2862-2868. [CrossRef] [PubMed]

127. Walter, S.; Weinschenk, T.; Stenzl, A.; Zdrojowy, R.; Pluzanska, A.; Szczylik, C.; Staehler, M.; Brugger, W.; Dietrich, P.Y.; Mendrzyk, R.; et al. Multipeptide immune response to cancer vaccine IMA901 after single-dose cyclophosphamide associates with longer patient survival. Nat. Med. 2012, 18, 1254-1261. [CrossRef] [PubMed]

128. Yao, X.; Ahmadzadeh, M.; Lu, Y.C.; Liewehr, D.J.; Dudley, M.E.; Liu, F.; Schrump, D.S.; Steinberg, S.M.; Rosenberg, S.A.; Robbins, P.F. Levels of peripheral CD4(+)FoxP3(+) regulatory T cells are negatively associated with clinical response to adoptive immunotherapy of human cancer. Blood 2012, 119, 5688-5696. [CrossRef] [PubMed]

129. Wolchok, J.D.; Kluger, H.; Callahan, M.K.; Postow, M.A.; Rizvi, N.A.; Lesokhin, A.M.; Segal, N.H.; Ariyan, C.E.; Gordon, R.A.; Reed, K.; et al. Nivolumab plus ipilimumab in advanced melanoma. N. Engl. J. Med. 2013, 369, 122-133. [CrossRef] [PubMed]

130. Topalian, S.L.; Sznol, M.; McDermott, D.F.; Kluger, H.M.; Carvajal, R.D.; Sharfman, W.H.; Brahmer, J.R.; Lawrence, D.P.; Atkins, M.B.; Powderly, J.D.; et al. Survival, durable tumor remission, and long-term safety in patients with advanced melanoma receiving nivolumab. J. Clin. Oncol. 2014, 32, 1020-1030. [CrossRef] [PubMed]

131. Postow, M.A.; Callahan, M.K.; Wolchok, J.D. Immune Checkpoint Blockade in Cancer Therapy. J. Clin. Oncol. 2015, 33, 1974-1982. [CrossRef] [PubMed]

132. Ansell, S.M.; Lesokhin, A.M.; Borrello, I.; Halwani, A.; Scott, E.C.; Gutierrez, M.; Schuster, S.J.; Millenson, M.M.; Cattry, D.; Freeman, G.J.; et al. PD-1 blockade with nivolumab in relapsed or refractory Hodgkin's lymphoma. N. Engl. J. Med. 2015, 372, 311-319. [CrossRef] [PubMed]

133. Maker, A.V.; Attia, P.; Rosenberg, S.A. Analysis of the cellular mechanism of antitumor responses and autoimmunity in patients treated with CTLA-4 blockade. J. Immunol. 2005, 175, 7746-7754. [CrossRef] [PubMed]

134. O'Mahony, D.; Morris, J.C.; Quinn, C.; Gao, W.; Wilson, W.H.; Gause, B.; Pittaluga, S.; Neelapu, S.; Brown, M.; Fleisher, T.A.; et al. A pilot study of CTLA-4 blockade after cancer vaccine failure in patients with advanced malignancy. Clin. Cancer Res. 2007, 13, 958-964. [CrossRef] [PubMed]

135. Menard, C.; Ghiringhelli, F.; Roux, S.; Chaput, N.; Mateus, C.; Grohmann, U.; Caillat-Zucman, S.; Zitvogel, L.; Robert, C. Ctla-4 blockade confers lymphocyte resistance to regulatory T-cells in advanced melanoma: Surrogate marker of efficacy of tremelimumab? Clin. Cancer Res. 2008, 14, 5242-5249. [CrossRef] [PubMed]

136. Ribas, A.; Comin-Anduix, B.; Economou, J.S.; Donahue, T.R.; de la Rocha, P.; Morris, L.F.; Jalil, J.; Dissette, V.B.; Shintaku, I.P.; Glaspy, J.A.; et al. Intratumoral immune cell infiltrates, FoxP3, and indoleamine 2,3-dioxygenase in patients with melanoma undergoing CTLA4 blockade. Clin. Cancer Res. 2009, 15, 390-399. [CrossRef] [PubMed]

137. Ralph, C.; Elkord, E.; Burt, D.J.; O’Dwyer, J.F.; Austin, E.B.; Stern, P.L.; Hawkins, R.E.; Thistlethwaite, F.C. Modulation of lymphocyte regulation for cancer therapy: A phase II trial of tremelimumab in advanced gastric and esophageal adenocarcinoma. Clin. Cancer Res. 2010, 16, 1662-1672. [CrossRef] [PubMed]

138. Khan, S.; Burt, D.J.; Ralph, C.; Thistlethwaite, F.C.; Hawkins, R.E.; Elkord, E. Tremelimumab (anti-CTLA4) mediates immune responses mainly by direct activation of $\mathrm{T}$ effector cells rather than by affecting $\mathrm{T}$ regulatory cells. Clin. Immunol. 2011, 138, 85-96. [CrossRef] [PubMed]

139. Weber, J.S.; Hamid, O.; Chasalow, S.D.; Wu, D.Y.; Parker, S.M.; Galbraith, S.; Gnjatic, S.; Berman, D. Ipilimumab increases activated $\mathrm{T}$ cells and enhances humoral immunity in patients with advanced melanoma. J. Immunother. 2012, 35, 89-97. [CrossRef] [PubMed]

140. Tarhini, A.A.; Butterfield, L.H.; Shuai, Y.; Gooding, W.E.; Kalinski, P.; Kirkwood, J.M. Differing patterns of circulating regulatory $\mathrm{T}$ cells and myeloid-derived suppressor cells in metastatic melanoma patients receiving anti-CTLA4 antibody and interferon-alpha or TLR-9 agonist and GM-CSF with peptide vaccination. J. Immunother. 2012, 35, 702-710. [CrossRef] [PubMed] 
141. Tarhini, A.A.; Edington, H.; Butterfield, L.H.; Lin, Y.; Shuai, Y.; Tawbi, H.; Sander, C.; Yin, Y.; Holtzman, M.; Johnson, J.; et al. Immune monitoring of the circulation and the tumor microenvironment in patients with regionally advanced melanoma receiving neoadjuvant ipilimumab. PLoS ONE 2014, 9, e87705. [CrossRef] [PubMed]

142. Smyth, M.J.; Ngiow, S.F.; Teng, M.W. Targeting regulatory T cells in tumor immunotherapy. Immunol. Cell Biol. 2014, 92, 473-474. [CrossRef] [PubMed]

143. Furness, A.J.; Vargas, F.A.; Peggs, K.S.; Quezada, S.A. Impact of tumour microenvironment and Fc receptors on the activity of immunomodulatory antibodies. Trends Immunol. 2014, 35, 290-298. [CrossRef] [PubMed]

144. Jie, H.B.; Schuler, P.J.; Lee, S.C.; Srivastava, R.M.; Argiris, A.; Ferrone, S.; Whiteside, T.L.; Ferris, R.L. CTLA-4(+) Regulatory T Cells Increased in Cetuximab-Treated Head and Neck Cancer Patients Suppress NK Cell Cytotoxicity and Correlate with Poor Prognosis. Cancer Res. 2015, 75, 2200-2210. [CrossRef] [PubMed]

145. Romano, E.; Kusio-Kobialka, M.; Foukas, P.G.; Baumgaertner, P.; Meyer, C.; Ballabeni, P.; Michielin, O.; Weide, B.; Romero, P.; Speiser, D.E. Ipilimumab-dependent cell-mediated cytotoxicity of regulatory T cells ex vivo by nonclassical monocytes in melanoma patients. Proc. Natl. Acad. Sci. USA 2015, 112, 6140-6145. [CrossRef] [PubMed]

146. Hou, T.Z.; Qureshi, O.S.; Wang, C.J.; Baker, J.; Young, S.P.; Walker, L.S.; Sansom, D.M. A transendocytosis model of CTLA-4 function predicts its suppressive behavior on regulatory T cells. J. Immunol. 2015, 194, 2148-2159. [CrossRef] [PubMed]

147. Sarnaik, A.A.; Yu, B.; Yu, D.; Morelli, D.; Hall, M.; Bogle, D.; Yan, L.; Targan, S.; Solomon, J.; Nichol, G.; et al. Extended dose ipilimumab with a peptide vaccine: Immune correlates associated with clinical benefit in patients with resected high-risk stage IIIc/IV melanoma. Clin. Cancer Res. 2011, 17, 896-906. [CrossRef] [PubMed]

148. Bjoern, J.; Juul Nitschke, N.; Zeeberg Iversen, T.; Schmidt, H.; Fode, K.; Svane, I.M. Immunological correlates of treatment and response in stage IV malignant melanoma patients treated with Ipilimumab. Oncoimmunology 2016, 5, e1100788. [CrossRef] [PubMed]

149. Liakou, C.I.; Kamat, A.; Tang, D.N.; Chen, H.; Sun, J.; Troncoso, P.; Logothetis, C.; Sharma, P. CTLA-4 blockade increases IFNgamma-producing CD4+ICOShi cells to shift the ratio of effector to regulatory T cells in cancer patients. Proc. Natl. Acad. Sci. USA 2008, 105, 14987-14992. [CrossRef] [PubMed]

150. Martens, A.; Wistuba-Hamprecht, K.; Yuan, J.; Postow, M.A.; Wong, P.; Capone, M.; Madonna, G.; Khammari, A.; Schilling, B.; Sucker, A.; et al. Increases in absolute lymphocytes and circulating CD4+ and CD8+ T cells are associated with positive clinical outcome of melanoma patients treated with ipilimumab. Clin. Cancer Res. 2016. [CrossRef] [PubMed]

151. Wang, W.; Lau, R.; Yu, D.; Zhu, W.; Korman, A.; Weber, J. PD1 blockade reverses the suppression of melanoma antigen-specific CTL by CD4+ CD25(Hi) regulatory T cells. Int. Immunol. 2009, 21, 1065-1077. [CrossRef] [PubMed]

152. Wang, C.; Thudium, K.B.; Han, M.; Wang, X.T.; Huang, H.; Feingersh, D.; Garcia, C.; Wu, Y.; Kuhne, M.; Srinivasan, M.; et al. In vitro characterization of the anti-PD-1 antibody nivolumab, BMS-936558, and in vivo toxicology in non-human primates. Cancer Immunol. Res. 2014, 2, 846-856. [CrossRef] [PubMed]

153. Weber, J.S.; Kudchadkar, R.R.; Yu, B.; Gallenstein, D.; Horak, C.E.; Inzunza, H.D.; Zhao, X.; Martinez, A.J.; Wang, W.; Gibney, G.; et al. Safety, efficacy, and biomarkers of nivolumab with vaccine in ipilimumab-refractory or -naive melanoma. J. Clin. Oncol. 2013, 31, 4311-4318. [CrossRef] [PubMed]

154. Gibney, G.T.; Kudchadkar, R.R.; DeConti, R.C.; Thebeau, M.S.; Czupryn, M.P.; Tetteh, L.; Eysmans, C.; Richards, A.; Schell, M.J.; Fisher, K.J.; et al. Safety, correlative markers, and clinical results of adjuvant nivolumab in combination with vaccine in resected high-risk metastatic melanoma. Clin. Cancer Res. 2015, 21, 712-720. [CrossRef] [PubMed]

155. Tsai, K.K.; Daud, A.I. Nivolumab plus ipilimumab in the treatment of advanced melanoma. J. Hematol. Oncol. 2015. [CrossRef] [PubMed]

156. Bowyer, S.; Prithviraj, P.; Lorigan, P.; Larkin, J.; McArthur, G.; Atkinson, V.; Millward, M.; Khou, M.; Diem, S.; Ramanujam, S.; et al. Efficacy and toxicity of treatment with the anti-CTLA-4 antibody ipilimumab in patients with metastatic melanoma after prior anti-PD-1 therapy. Br. J. Cancer 2016, 114, 1084-1089. [CrossRef] [PubMed]

157. Lumniczky, K.; Safrany, G. The impact of radiation therapy on the antitumor immunity: Local effects and systemic consequences. Cancer Lett. 2015, 356, 114-125. [CrossRef] [PubMed] 
158. Di Maggio, F.M.; Minafra, L.; Forte, G.I.; Cammarata, F.P.; Lio, D.; Messa, C.; Gilardi, M.C.; Bravata, V. Portrait of inflammatory response to ionizing radiation treatment. J. Inflamm. (Lond.) 2015. [CrossRef] [PubMed]

159. Persa, E.; Balogh, A.; Safrany, G.; Lumniczky, K. The effect of ionizing radiation on regulatory T cells in health and disease. Cancer Lett. 2015, 368, 252-261. [CrossRef] [PubMed]

160. Battaglia, A.; Buzzonetti, A.; Martinelli, E.; Fanelli, M.; Petrillo, M.; Ferrandina, G.; Scambia, G.; Fattorossi, A. Selective changes in the immune profile of tumor-draining lymph nodes after different neoadjuvant chemoradiation regimens for locally advanced cervical cancer. Int. J. Radiat. Oncol. Biol. Phys. 2010, 76, 1546-1553. [CrossRef] [PubMed]

161. Fadul, C.E.; Fisher, J.L.; Gui, J.; Hampton, T.H.; Cote, A.L.; Ernstoff, M.S. Immune modulation effects of concomitant temozolomide and radiation therapy on peripheral blood mononuclear cells in patients with glioblastoma multiforme. Neuro Oncol. 2011, 13, 393-400. [CrossRef] [PubMed]

162. Schuler, P.J.; Harasymczuk, M.; Schilling, B.; Saze, Z.; Strauss, L.; Lang, S.; Johnson, J.T.; Whiteside, T.L. Effects of adjuvant chemoradiotherapy on the frequency and function of regulatory $\mathrm{T}$ cells in patients with head and neck cancer. Clin. Cancer Res. 2013, 19, 6585-6596. [CrossRef] [PubMed]

163. Sekar, D.; Hahn, C.; Brune, B.; Roberts, E.; Weigert, A. Apoptotic tumor cells induce IL-27 release from human DCs to activate Treg cells that express CD69 and attenuate cytotoxicity. Eur. J. Immunol. 2012, 42, 1585-1598. [CrossRef] [PubMed]

164. Postow, M.A.; Callahan, M.K.; Barker, C.A.; Yamada, Y.; Yuan, J.; Kitano, S.; Mu, Z.; Rasalan, T.; Adamow, M.; Ritter, E.; et al. Immunologic correlates of the abscopal effect in a patient with melanoma. N. Engl. J. Med. 2012, 366, 925-931. [CrossRef] [PubMed]

165. Golden, E.B.; Demaria, S.; Schiff, P.B.; Chachoua, A.; Formenti, S.C. An abscopal response to radiation and ipilimumab in a patient with metastatic non-small cell lung cancer. Cancer Immunol. Res. 2013, 1, 365-372. [CrossRef] [PubMed]

166. Twyman-Saint Victor, C.; Rech, A.J.; Maity, A.; Rengan, R.; Pauken, K.E.; Stelekati, E.; Benci, J.L.; Xu, B.; Dada, H.; Odorizzi, P.M.; et al. Radiation and dual checkpoint blockade activate non-redundant immune mechanisms in cancer. Nature 2015, 520, 373-377. [CrossRef] [PubMed]

167. Janik, J.E.; Morris, J.C.; O’Mahony, D.; Pittaluga, S.; Jaffe, E.S.; Redon, C.E.; Bonner, W.M.; Brechbiel, M.W.; Paik, C.H.; Whatley, M.; et al. 90Y-daclizumab, an anti-CD25 monoclonal antibody, provided responses in $50 \%$ of patients with relapsed Hodgkin's lymphoma. Proc. Natl. Acad. Sci. USA 2015, 112, 13045-13050. [CrossRef] [PubMed]

168. S Ghiringhelli, F.; Menard, C.; Puig, P.E.; Ladoire, S.; Roux, S.; Martin, F.; Solary, E.; Le Cesne, A.; Zitvogel, L.; Chauffert, B. Metronomic cyclophosphamide regimen selectively depletes $\mathrm{CD} 4{ }^{+} \mathrm{CD} 25^{+}$regulatory T cells and restores $\mathrm{T}$ and NK effector functions in end stage cancer patients. Cancer Immunol. Immunother. 2007, 56, 641-648. [CrossRef] [PubMed]

169. Ge, Y.; Domschke, C.; Stoiber, N.; Schott, S.; Heil, J.; Rom, J.; Blumenstein, M.; Thum, J.; Sohn, C.; Schneeweiss, A.; et al. Metronomic cyclophosphamide treatment in metastasized breast cancer patients: Immunological effects and clinical outcome. Cancer Immunol. Immunother. 2012, 61, 353-362. [CrossRef] [PubMed]

170. Cha, E.; Klinger, M.; Hou, Y.; Cummings, C.; Ribas, A.; Faham, M.; Fong, L. Improved survival with T cell clonotype stability after anti-CTLA-4 treatment in cancer patients. Sci. Transl. Med. 2014. [CrossRef] [PubMed]

171. Kvistborg, P.; Philips, D.; Kelderman, S.; Hageman, L.; Ottensmeier, C.; Joseph-Pietras, D.; Welters, M.J.; van der Burg, S.; Kapiteijn, E.; Michielin, O.; et al. Anti-CTLA-4 therapy broadens the melanoma-reactive CD8+ T cell response. Sci. Transl. Med. 2014. [CrossRef] [PubMed]

172. Tumeh, P.C.; Harview, C.L.; Yearley, J.H.; Shintaku, I.P.; Taylor, E.J.; Robert, L.; Chmielowski, B.; Spasic, M.; Henry, G.; Ciobanu, V.; et al. PD-1 blockade induces responses by inhibiting adaptive immune resistance. Nature 2014, 515, 568-571. [CrossRef] [PubMed]

(C) 2016 by the authors; licensee MDPI, Basel, Switzerland. This article is an open access article distributed under the terms and conditions of the Creative Commons Attribution (CC-BY) license (http:/ / creativecommons.org/licenses/by/4.0/). 